\title{
Lysimeters at the Hanford Site: Present Use and Future Needs
}

\author{
G. W. Gee \\ T. L. Jones
}

October 1985

Prepared for the U.S. Department of Energy under Contract DE-AC06-76RLO 1830

Pacific Northwest Laboratory Operated for the U.S. Department of Energy by Battelle Memorial Institute 


\title{
DISCLAIMER
}

This report was prepared as an account of work sponsored by an agency of the United States Government. Neither the United States Government nor any agency thereof, nor any of their employees, makes any warranty, express or implied, or assumes any legal liability or responsibility for the accuracy, completeness, or usefulness of any information, apparatus, product, or process disclosed, or represents that its use would not infringe privately owned rights. Reference herein to any specific commercial product, process, or service by trade name, trademark, manufacturer, or otherwise, does not necessarily constitute or imply its endorsement, recommendation, or favoring by the United States Government or any agency thereof. The views and opinions of authors expressed herein do not necessarily state or reflect those of the United States Government or any agency thereof.

\author{
PACIFIC NORTHWEST LABORATORY \\ operated by \\ BATTELLE \\ for the \\ UNITED STATES DEPARTMENT OF ENERGY \\ under Contract DE-AC06-76RLO 1830
}

\begin{tabular}{|c|c|}
\hline \multicolumn{2}{|c|}{ Printed in the United States of America } \\
\hline \multicolumn{2}{|c|}{ Available from } \\
\hline \multirow{2}{*}{\multicolumn{2}{|c|}{$\begin{array}{l}\text { National Technical Information Service } \\
\text { United States Department of Commerce }\end{array}$}} \\
\hline & \\
\hline \multicolumn{2}{|c|}{ Springfield, Virginia 22161} \\
\hline \multirow{2}{*}{\multicolumn{2}{|c|}{$\begin{array}{l}\text { NTIS Price Codes } \\
\text { Microfiche A01 }\end{array}$}} \\
\hline & \\
\hline \multicolumn{2}{|c|}{ Printed Copy } \\
\hline & Price \\
\hline Pages & Codes \\
\hline $001-025$ & $\mathrm{~A} 02$ \\
\hline $026-050$ & $\mathrm{~A} 03$ \\
\hline $051-075$ & $\mathrm{~A} 04$ \\
\hline $076-100$ & A05 \\
\hline $101-125$ & A06 \\
\hline $126-150$ & $\mathrm{~A} 07$ \\
\hline $151-175$ & A08 \\
\hline $176-200$ & A09 \\
\hline $201-225$ & A010 \\
\hline $226-250$ & A011 \\
\hline $251-275$ & A 012 \\
\hline $276-300$ & A013 \\
\hline
\end{tabular}


LYSIMETERS AT THE HANFORD SITE :

PRESENT USE AND FUTURE NEEDS

G. W. Gee

T. L. Jones

October 1985

Prepared for

the U.S. Department of Energy

under Contract DE-ACO6-76RLO 1830

Pacific Northwest Laboratory

Richland, Washington 99352 


\section{EXECUTIVE SUMMARY}

Lysimeters have been built and used at the Hanford Site for a variety of reasons, including the assessment of recharge (drainage) rates, biointrusion studies, the development of shallow-land burial monitoring and measurement methods, radionuclide transport studies, evapotranspiration studies, and fieldscale waste-form leaching tests. A common feature of lysimeters is that they provide a way either to directly measure or to estimate water balance parameters such as soil-water storage changes, evapotranspiration, and drainage for a given site. The number of water balance parameters and the precision with which they can be measured vary depending on the design features of the lysimeter. In this report we describe key design features of the six major lysimeters facilities at Hanfard and the types of data available from them. We also address the deficiencies of the present facilities for adequately determining recharge rates and propose additional facilities to evaluate protective barrier systems and arid-1and water dynamics.

Weighing lysimeters in the 300 Area and at the Arid Lands Ecology Reserve have provided the only evapotranspiration data available on the Hanford Site. No direct measurement of either recharge or evapotranspiration has been made at any of the waste sites at Hanford. Additional onsite measurements, made using either weighing lysimeters or nonweighing lysimeters equipped with drainage collection devices are needed. Only then can the questions regarding recharge at Hanford be properly addressed.

Proposed lysimeter studies for evaluating the protective barrier systems for the Hanford Waste Management Technology Program and for evaluating arid1 and water dynamics for the Arid Lands Ecology program will supplement the present data base on water balance parameters at Hanford. In addition, maintaining the present lysimeter facilities in the 200 and 300 Areas will provide a needed continuity of record for long-term predictive modeling.

Finally, additional studies needed to resolve recharge questions include in situ hydraulic conductivity testing, micrometeorological measurements of evapotranspiration, and tracer studies of travel time in the unsaturated zone of layered soils. These studies are presently being planned. 
CONTENTS

EXECUTIVE SUMMARY...................................

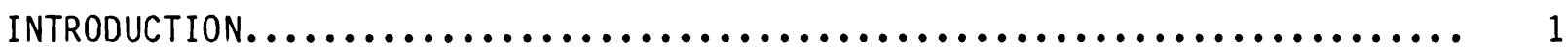

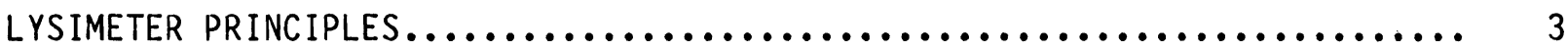

UNIQUE FEATURES...................................... 7

DESIGN CRITERIA.................................. 10

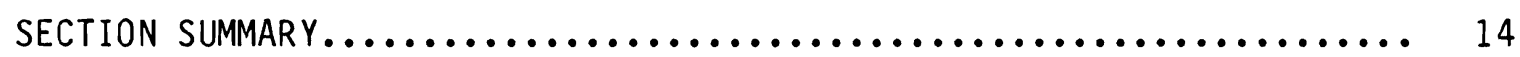

PAST AND PRESENT LYSIMETER FACILITIES AT HANFORD ................ 17

LYSIMETER FACILITY 1: 200-E AREA ROCKWELL LYSIMETERS .......... 17

LYSIMETER FACILITY 2: BIOINTRUSION LYSIMETERS............... 22

LYSIMETER FACILITY 3: BURIED-WASTE TEST FACILITY LYSIMETERS . . . . . . 24

LYSIMETER FACILITY 4: COMMERCIAL-WASTE TEST FACILITY LYSIMETERS.... 27

LYSIMETER FACILITY 5: GROUT WASTE TEST FACILITY LYSIMETERS ........ 29

LYSIMETER FACILITY 6: ALE RESERVE LYSIMETERS................. 29

SECTION SUMMARY................................ 32

LYSIMETER NEEDS ................................... 34

MODEL EVALUATION..................................... 34

PROTECTIVE-BARRIER STUDIES .......................... 38

ALE SITE WATER DYNAMICS STUDY........................ 38

ADDITIONAL WATER BALANCE STUDIES AT HANFORD $\ldots \ldots \ldots \ldots \ldots \ldots \ldots \ldots \ldots$

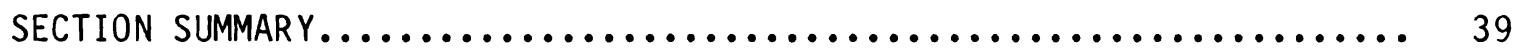

REFERENCES....................................... 41 


\section{FIGURES}

1 Annual Water Balance at the Hanford Site.................... 4

2 Locations of Lysimeter Facilities at the Hanford Site............. 19

3 Schematic Diagram of 18-m-Deep Caisson Lysimeters in

the $200-\mathrm{E}$ Area.......................................... 20

4 Schematic Diagram of Biointrusion Lysimeters in the

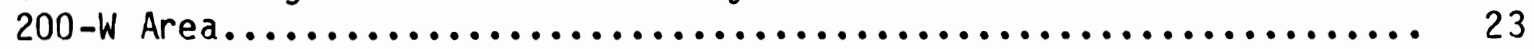

5 Schematic Diagram of the Lysimeters at the Buried-Waste

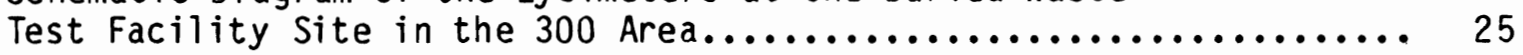

6 Schematic Diagram of Weighing Lysimeters at the Buried-Waste

Test Facility Site in the 300 Area......................... 26

7 Schematic Diagram of Lysimeters at the Commercial-Waste Test

Facility in the 300 Area ............................... 28

8 Schematic Diagram of Lysimeters at the Grout Waste Test

Facility in the 300 Area................................ 30

9 Schematic Diagram of Smal1 Weighing Lysimeters at the Arid

Lands Ecology Reserve.................................

\section{TABLES}

1 Lysimeter Features Useful for Studies of Water Balance and Solute

Transport in Unsaturated Zones............................ 16

2 Lysimeter Facilities at the Hanford Site................... 18

3 Measurement Capabilities of Hanford Lysimeter Facilities.......... 33

4 Reported Estimates of Recharge at Selected Arid Sites............ 35 


\section{INTRODUCTION}

Pacific Northwest Laboratory (PNL) initiated the program "Site Performance Assessment for the Disposal of Hanford Defense Waste" in fiscal year 1985. The program is part of the overall Hanford Waste Management Technology Plan (U.S. Department of Energy 1984). The objectives of the performance assessment program are threefold:

- to evaluate the effectiveness of various disposal options in protecting present and future humans and their environment from Hanford defense waste

- to develop and maintain the analytical techniques, models, and data bases necessary to assess postulated disposal actions on a systems performance basis

- to provide a technical basis for decisions concerning site selection, conceptual systems design, system tradeoff studies, development of criteria and standards, and research and development priorities.

The program, to date, has focused on the hydrologic consequences related to inplace waste disposal at Hanford.

One task in the program is directed toward developing an unsaturated-flow modeling capability and enhancing the data base of unsaturated (vadose-zone) water flow and transport. As part of this task, a review of unsaturated-flow studies at Hanford was published (Gee and Heller 1985). The review covered the status of a variety of vadose-zone water balance studies, including field measurements and model simulations of such diverse processes as evapotranspiration, recharge (drainage), and nonisothermal flow. These studies have come to different conclusions about the quantities of recharge that might be present at Hanford. Since there are such striking differences in recharge estimates from lysimeters, PNL was asked to prepare a document explaining the likely causes for these differences as well as outlining the use of lysimetry and the present status of and future needs for lysimeters at Hanford. 
The intent of this report is to summarize the history and current status of lysimeter facilities at Hanford. The report is divided into three sections. The first section provides some introductory comments on lysimeter design and the application of lysimetry to water balance and solute transport studies. The second section describes the present lysimeter facilities at Hanford and the type of data generated from them. The final section details future needs by describing proposed lysimeter facilities and making recommendations for additional water balance studies at Hanford. 


\section{LYSIMETER PRINCIPLES}

Lysimeters are commonly used in hydrologic research to quantify the amount of water that is stored in or lost from a volume of soil (Howell 1957; Marshall and Holmes 1979; Hillel 1982). In its simplest form, a lysimeter is a container of soil that has been buried flush with the ground surface. Lysimeters can range in size from small soil-filled cans, a few centimeters in diameter and a few centimeters deep (Boast and Robertson 1982), to large caissons that are several meters wide and tens of meters deep (Hsieh, Brownell and Reisenauer 1973).

Lysimeters can be simply designed with little or no peripheral instrumentation (Hinds 1973), or they can be designed with extensive monitoring features, including devices for monitoring soil temperature, soil water content and matric potential, and local meteorological conditions, and devices for extracting samples of soil water for chemical analysis (Phillips et al. 1979). The size, type, and degree of instrument complexity of a lysimeter depend on the particular application for which it was designed.

Recent reports on unsaturated-zone monitoring have referred to certain sampling devices, used to remove pore water from partially saturated soils, as "lysimeters" (U.S. Environmental Protection Agency 1982; Morrison 1983;

Morrison and Szecsody 1985). These devices are not containers of soil but are porous cups inserted at depth in the soil. The cups are made of ceramic, stainless steel, or Teflon, and are connected to a vacuum system in order to collect a solution sample of pore water from unsaturated soil. The samplers are also referred to as suction lysimeters, suction candles, or pore-water samplers. In this report we will be using the term lysimeter solely to mean a container of soil. However, lysimeters often will have suction candles in them as part of the instrumentation package.

The design features of lysimeters allow them to be used to varying degrees for water balance studies. The water balance of a lysimeter can be written as

\footnotetext{
( ${ }^{-T e f l o n}$ is a trademark of E. I. du Pont de Nemours Company, Wilmington, Delaware.
} 


$$
P=\Delta S+E T+D+R
$$

where $P$ is precipitation, $\Delta S$ is water storage change, ET is evapotranspiration, $D$ is drainage, and $R$ is runoff (or runon). In the absence of runoff, the water balance relates the precipitation directly to the sum of the water storage changes plus evapotranspiration and drainage. At the Hanford Site the water balance components ( $P, \Delta S, E T$, and $D)$ can vary markedly with time (Figure 1 ).

In theory, water balance calculations are one way to check how well we can account for the water transport and distribution at a site. If, for example, the water balance calculations cannot account for the amount of drainage independently observed at a given site, then we know that we are either measuring or calculating one or more of the other water balance terms incorrectly. In practice, however, one or more of the water balance terms cannot be measured and must be calculated by difference. The use of properly equipped lysimeters allows for more accurate measurement of water balance components and therefore increases the usefulness and accuracy of any water balance calculation. Analyzing the experimental designs needed to measure water balance with and without lysimeters will illustrate the usefulness and limitations of lysimetry.

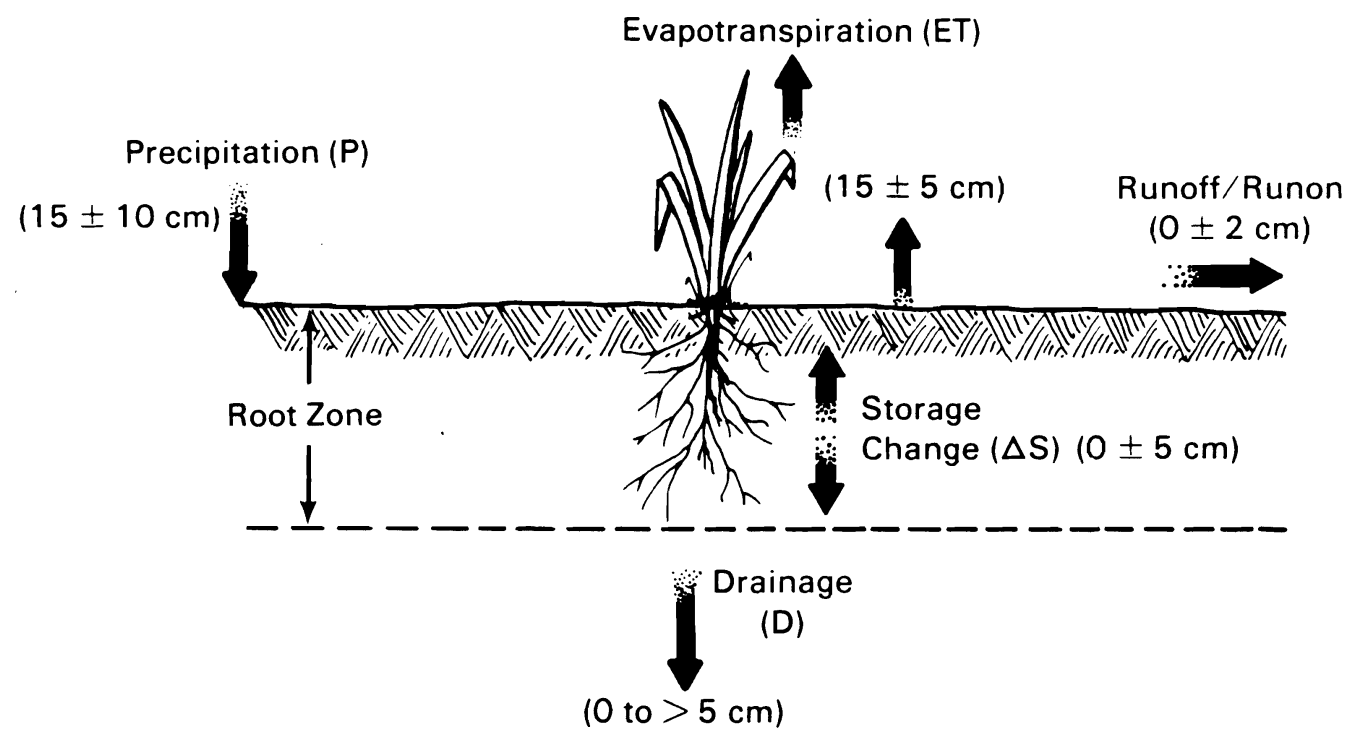

FIGURE 1. Annual Water Balance at the Hanford Site 
CASE 1: No lysimeter. Study site instrumented with neutron probe access tubes and rain gauge.

In this situation the only direct measurements available are water content via neutron probe and precipitation via rain gauge. Therefore, we have a direct measurement of $P$ and an indirect measurement of $S$ by integrating the water content profile obtained from neutron probe data. We can then estimate $\Delta S$ by comparing neutron probe data through time. Therefore, we measure $P$, estimate $\Delta S$ and calculate $E T+D+R$ by difference. An example of this type of analysis is given by Gee and Kirkham (1984) for a grass-covered area on the Hanford Site.

We can further calculate an estimate of drainage (D) from the neutron probe data by using Darcy's Law; if the measured water content changes with depth do not show much variation with time, we can assume steady drainage (downward water flux). With that assumption the Darcy flux can be calculated in one of two ways, depending on the data available. For conditions of onedimensional steady flow, drainage flux can be calculated from known hydraulic conductivity and measured hydraulic gradients as

$$
\text { flux }=-k(\psi)[d \psi / d z+1]=\text { const. }
$$

where $\psi$ is the matric potential, $[d \psi / d z+1]$ is the total hydraulic gradient, and depth is measured with $z$ positive upward. Such an analysis requires direct measurement of the matric potential using tensiometers or other devices (Hillel 1982). If the only data available are for water content $(\theta)$, then an estimate of matric potential can be obtained from a soil-water characteristic curve [i.e., $\psi(\theta)$ relationship].

Under conditions where the water content profile is uniform and the soil is known to be uniform, the usual approach is to assume that a uniform water content implies a uniform matric potential. Therefore, $d \psi / d z=0$, leaving the gravity potential to dominate the hydraulic-gradient term. The gravity gradient is by definition equal to $1 \mathrm{~cm} / \mathrm{cm}$; hence, the total hydraulic gradient is unity. This analysis is called the "unit gradient" approach (Hillel 1982). Under unit gradient conditions the flux or drainage rate is: 


$$
\text { flux }=-k(\theta)=\text { const. }
$$

This approach suggests that under the special condition of a homogeneous soil with uniform water content, the vertical flow is directly related to water content. Therefore, if the relationship of the unsaturated conductivity versus water content is known, the downward flux (drainage) can be determined from measured water content values.

An example of this approach, applied to a lysimeter without drainage collection capability, is given in an analysis of drainage of the 200-E Area Rockwell lysimeters (Jones 1978). Unfortunately, the unsaturated conductivity of this lysimeter soil has never been directly measured. Uncertainties in these kinds of flux estimates come from uncertainties in the relationship between hydraulic conductivity and water content/potential and from uncertainties in the field water content/potential. Jones (1978) showed that uncertainty in conductivity estimates, arising from uncertainty in the neutron probe data, alone can account for flow predictions ranging from $0.05 \mathrm{~cm} / \mathrm{yr}$ to $7.9 \mathrm{~cm} / \mathrm{yr}$ in the 200-E Area lysimeters. This estimate does not take into consideration the uncertainty in the $k(\theta)$ value, which in itself may exhibit absolute errors of more than one order of magnitude. A more reliable analysis approach is needed.

Taking into account the problems mentioned above, an estimate of drainage (D) in the water balance equation allows evapotranspiration (ET) to be calculated by difference (assuming that $R=0$ ). This is a poor estimate of $E T$; however, it is all that is possible without measuring drainage directly.

CASE 2: Nonweighing lysimeter equipped with drainage system. Site instrumented with neutron probe access tubes and rain gauge.

In this situation we can measure $P$ and $D$ directly and estimate $\Delta S$ from the neutron probe data as above. However, the presence of the lower boundary in the lysimeter reduces the accuracy of the neutron probe data and the subsequent estimates of $\Delta S$, especially if a water table is allowed to develop in the bottom of the lysimeter. Nonetheless, by using the measured values of $P, \Delta S$, and $D$, we can calculate ET (again assuming that $R=0$ ). This estimate of ET is better than that obtained in case 1 , because drainage is measured directly, and 
the measured value for drainage is substantially better than the calculated value described in case 1. An example of this kind of data set has been obtained from the Buried-Waste Test Facility in the 300 Area (Jones, Campbel1 and Gee 1984).

CASE 3: Weighing lysimeter equipped with drainage system. Site instrumented with neutron probe access tubes and rain gauge.

Water balance calculations at this lysimeter site consist of measured values of $P, D$, and $E T$. In cases 1 and 2, estimates of $S$ obtained from neutron probe data were treated as measured values. However, the uncertainty in those estimates can be large. With a weighing lysimeter, both ET and $\Delta S$ measurements are as accurate, for periods of time when no drainage or precipitation occurs, as the measured weight change; hence they can be quite precise $( \pm 0.1 \mathrm{~cm}$ or better). Collection of the neutron probe data is advisable since it provides additional data regarding water content distribution. However, it is not needed for water balance calculations.

\section{UNIQUE FEATURES}

The decision to use lysimeters in a field experiment must be made carefully. There are many advantages and disadvantages to using lysimeters, and the choice of lysimeters over alternative experimental designs must be motivated by the specific objectives of the project. An excellent review of lysimetry for water balance studies is given by Tanner (1967).

The most significant feature of a lysimeter is that it is basically a container of soil placed in the ground. The walls of this container form a physical boundary on the soil system being studied. The boundary defines a fixed volume of soil used to calculate water storage, restricts the geometry of flow within the lysimeter to one dimension, and wholly contains root systems and tracer plumes used for solute transport experiments. The lysimeter boundary can be a great advantage in some experiments but a disadvantage in others.

Most lysimeters are designed to include a means of collecting the drainage water from the bottom. Drainage water is defined as water that would have moved to a depth below the bottom of the lysimeter if the lysimeter bottom had not been there. The ability to make direct measurements of drainage is one of 
the great advantages of lysimeters and is especially important at Hanford, where the question of deep drainage is crucial to the study of waste management. However, in the case of shallow lysimeters, the assumption that water reaching the bottom of the lysimeter is really drainage water can be questioned. Also, a malfunctioning or poorly designed drainage system can result in artificial water tables forming in the lysimeter. Furthermore, shallow water tables tend to enhance evapotranspiration because the water is closer to the surface and can be evaporated more readily than water at deeper depths. Therefore, estimates of drainage from shallow lysimeters are generally lower than the actual drainage from adjacent sites.

In addition to drainage, some estimate of water storage is also made either by weighing or by neutron probe measurements. Having a fixed volume of soil, without any confounding lateral flow into or out of the lysimeter, greatly enhances the accuracy of the calculations involved in estimating both drainage and storage.

Having controlled flow boundaries is an advantage when plant water use and solute transport are being studied. For example, when plants grow naturally, root systems of the individual plants overlap and merge into an essentially uniform distribution of roots. This merging is especially true in grasses but can also be observed in plant communities consisting of sparsely populated shrubs and bushes such as sagebrush. A lysimeter boundary contains the root distribution within the box and does not allow the roots to merge with the roots of neighboring plants. This restriction is an advantage if individual plants need to be studied or if single-species populations need to be studied in areas where a mixed-species population occurs naturally.

Lysimetry can also be useful in a study of naturally occurring plant populations, where the plant community established in the lysimeter is identical in every way to the surrounding population. Lysimetry aids such a study for several reasons.

1. The relationship of root mass and density to top growth is an important parameter in the study of plant water use. If a lysimeter is not used, then assumptions must be made about the uniformity of root distributions and water use. 
2. The study of plant water uptake sometimes requires the measurement of plant parameters such as stomatal resistance and leaf water potential, which are known to be highly variable within even small communities. The ability to monitor these variables in plants whose roots are wholly contained in a fixed volume enhances our ability to relate changes in plant leaves to changes in the soil and roots.

3. The ability to measure the drainage component of the water balance enhances the accuracy of the evapotranspiration calculations.

A disadvantage of lysimetry in the study of plant water use is that plant behavior in a lysimeter can be different from that in a natural setting. Lysimeter-grown plants can easily have altered root densities and distributions and consequently different water use patterns. As will be explained later, this deficiency of lysimetry is critical if the data collected are to be used as direct measurements of the behavior of plants in the surrounding landscape. However, if the data are to be used for model evaluation studies, the problem is less critical. Plant studies in lysimeters are also disadvantageous if the plant canopy spreads out significantly over the edge of the lysimeter surface, since the canopy area would then be greater than the lysimeter soil surface area. The volume of water transpired is proportional to the canopy area. However, the roots are confined to, and pull water from, the cross-sectional area of the lysimeter. Hence, calculations of evapotranspiration in centimeters of water $\left(\mathrm{cm}^{3} \mathrm{H}_{2} \mathrm{O} / \mathrm{cm}^{2}\right.$ soil area) would be larger than in the natural setting, where canopy area and surface area are the same. This effect is most pronounced in smaller lysimeters.

The study of solute transport in unsaturated soils can be both enhanced and limited by lysimetry. The two most important controls in a tracer test are flow geometry and tracer recovery (i.e., mass balance). The latter is particularly important when studying sorbing or volatile tracers. Many tests of solute transport are designed to be one dimensional, and the data are interpreted using that assumption. When using a tracer on an open landscape, however, onedimensional flow is very difficult to control and can only be achieved by 
placing the tracer over a large area and studying the transport in the central portion of the plume. In contrast, one-dimensional flow is readily achievable in a lysimeter.

In any tracer test, the results are much more credible if the fate of all the tracer can be accounted for. If this happens we say that the tracer has been conserved or that we have mass balance. In experiments with nonsorbing and/or nonvolatile tracers, confining the region of flow to the lysimeter box and thus containing the tracer makes mass balance more likely.

A major limitation of lysimetry to solute transport study is in the study of dispersion. Solute dispersion is very sensitive to the large-scale heterogeneities of soil texture and density found in landscapes. These heterogeneities are impossible to duplicate in a lysimeter because of its size. Because most attempts to predict field-scale dispersion are highly empirical, any measurements obtained in a lysimeter would be difficult to extrapolate to solute transport on a field scale.

\section{DESIGN CRITERIA}

After the decision has been made to use lysimetry, a facility must be designed that will meet the objectives of the project. Those objectives usually require one or both of the following:

- using lysimeters to obtain measurements that are representative of what happens in the surrounding natural landscape--For this purpose, all of the water balance components inside the lysimeter must be equal to those outside.

- using the lysimeter data 1) for model input and 2) to evaluate how well a numerical model can predict the components of water balance from input such as weather conditions (climate) and soil properties-For this purpose, the water balance components inside and outside the lysimeter do not have to be equal but must be measured.

In addition to water balance data, climatic data and soil characterization data must be available. Ideally, we would like the lysimeter to produce data compatible with both objectives. However, the design of a lysimeter generally 
enhances the meeting of one objective at the expense of the other. Deciding which objective is the most important helps determine lysimeter location and construction specifications, as well as instrumentation and monitoring intensities.

Designing a lysimeter facility to collect data representative of field water balances requires a proper location and the duplication of hydrologic and biological properties of the landscape within the lysimeter. Choosing the location for such a lysimeter is critical to determining the lysimeter's usefulness since the data obtained will directly represent what is happening in only a small local area. For example, at Hanford choices must be made among the 100, 200, and 300 Areas and among tank farms, landfills, cribs, and undisturbed areas.

Recreating the in situ hydrologic properties of the surrounding area inside a lysimeter requires careful attention to packing densities and the preservation of any physical inhomogeneities. For highly structured soils, undisturbed cores or monoliths may need to be used. (See, for example, Brown et a1. 1974.) In waste management areas at Hanford, most of the soil material consists of unconsolidated sands. Because the differences between the hydrologic properties of undisturbed and disturbed samples of coarse sands are generally negligible, recreating these areas' hydrologic properties in a lysimeter is not highly problematic. In lysimeters designed to simulate deep profiles at waste areas or at the Arid Lands Ecology (ALE) Reserve on the Hanford Site, however, the local silt layers and lithologic discontinuities must be physically simulated.

Design problems can occur at the surface and lower boundaries of the lysimeter. At the very least, the surface of the lysimeter must be carefully constructed to minimize differences in infiltration/runoff characteristics. In the case of a vegetated lysimeter, the duplication of a plant distribution representative of the field is a difficult problem. The type of plants, their density and speciation, and the rooting densities all affect plant water use. Establishing and maintaining appropriate plant communities on vegetated lysimeters may be the most difficult task in lysimetry. 
The design of the drainage system at the bottom of the lysimeter is important. The bottom of the lysimeter represents a boundary that is not present in the natural landscape. In shallow lysimeters an artificial water table can quickly develop that can perturb the entire water content profile, as well as drainage rates relative to the surroundings. For most water balance studies a method of removing the drainage water is utilized in the lysimeter design. Sintered metal plates (Ritchie and Burnett 1968) or ceramic cups (Brown et a1. 1974; Kirkham, Gee and Jones 1984) attached to a vacuum system and placed at the bottom of the lysimeter can be used to remove water and maintain a desired matric water potential. The controlled level of matric potential depends on numerous choices but can be tied to the matric potential observed on the outside of the lysimeter (Tanner 1967).

In contrast, for studies of protective barrier systems, which have shallow ( $1.5 \mathrm{~m}$ or less) soil layers, the presence of an artificial boundary (or water table) at the bottom of the soil layer is needed to analyze the system performance. In such a study, only a free-drainage system would be required. For example, a 1.5-m-deep lysimeter, similar to the Buried-Waste Test Facility weighing lysimeters at Hanford, would be appropriate for measuring evapotranspiration from a soil cover used in a protective barrier.

A lysimeter used to provide model input and model output comparison data is somewhat easier to design because the need to duplicate natural conditions is not as great. For example, if a lysimeter is packed with a certain soil found in the area of interest but not to the exact field density, the data collected are still very useful in terms of evaluating model performance. The model will predict flow within the lysimeter based on the actual density of the lysimeter soil and the actual hydraulic conductivity. If the model predicts flow within the lysimeter adequately, we can assume that it will adequately predict water flow outside the lysimeter given the actual field density and conductivity. Although the observations made in the lysimeter cannot be used as direct measurements of the flow in the field, they do help build confidence that the model can predict the field flow.

A major limitation to the use of lysimetry in model evaluation is found when the lysimeter is designed with soil and plant conditions that differ 
greatly from those in the field (i.e., if the processes taking place in the field are not represented in the lysimeter). An extreme example would be using a successful simulation of water flow in a bare-soil lysimeter as proof of the ability to model water flow in a vegetated field. A more subtle example would be modeling a lysimeter experiment in which no extreme events such as runoff caused by isolated heavy storms or extreme temperature conditions such as freezing were recorded. The resulting data would not indicate how well the model will predict what happens under these conditions. (The latter scenario illustrates why the use of a field lysimeter is better than a laboratory study even if the lysimeter is not an exact duplication of the rest of the field: field weather conditions cannot easily be generated.

A second limitation to the use of lysimetry in model evaluation is found when the model being evaluated is largely empirical. For example, lysimetry may be used to generate a crop coefficient for a plant community, that is, an empirical relationship describing plant water use. The crop coefficient depends on root density, plant cover, and plant species, some of which do not appear explicitly in the model. Therefore, unless you know that the relevant conditions inside the lysimeter are the same as those outside the lysimeter, the measured crop coefficient may not be valid except in the lysimeter. Lysimetry can be used to show that, given the correct parameters, empirical models work, but using lysimetry data to generate empirical models can be misleading.

The most important design criterion for a lysimeter used in model evaluation is whether the data needed for the model evaluation can be adequately collected. For example, a water balance model has several outputs, including water content, drainage and evapotranspiration rates, storage changes, and redistribution rates. The model can be evaluated on the basis of how well the predictions of any of these quantities match measured values. The most common criterion used in the literature to evaluate a model's performance is water content distributions. However, as stated above, water content distributions are difficult to measure accurately in lysimeters or any other layered system such as protective barriers. If water content is the criterion that will be used to evaluate a model, then lysimeters should not be used as part of the 
experimental design. Other criteria such as storage, drainage, and evapotranspiration can also be used to evaluate a model, and these quantities are measured nicely by lysimeters.

Another consideration in the design of lysimeters that will generate data used in modeling is the input requirements of the model. The input data are just as important as the lysimeter output data. For example, various meteorological parameters are needed as input by most water flow models. Data collected at a lysimeter facility that does not include meteorological information are of limited value when the objective of the lysimeter is model testing. The worst possible design for a lysimeter is one that meets none of the required objectives (i.e., it does not duplicate flow conditions outside the lysimeter and does not provide enough information to be useful in modeling studies).

\section{SECTION SUMMARY}

The first step in choosing lysimetry over alternative experimental designs is deciding whether drainage, storage, and/or evapotranspiration rates need to be explicitly measured, and whether root systems and/or solute tracers need to be contained within a fixed volume of soil. The second step is weighing the advantages of making these measurements against the disadvantages of less accurate measurements of water content distribution, and recognizing the possibility that lysimeter measurements may not directly represent measurements in undisturbed soils, and that point measurements are not the same as area-wide measurements. The final step is deciding whether the lysimeter measurements will be interpreted as direct field observations or used for model validation/ verification studies only.

If the measurements are to be interpreted as representative field observations and cannot be adequately duplicated in a lysimeter, then lysimetry is not recommended. On the other hand, if the data are to be used primarily for model testing and development, then lysimetry is recommended since lysimetry delivers the information most needed by the model ( $i . e$. , it provided either direct input data or comparisons with model output).

Lysimeters can be monitored at depth with neutron probes for moisture content changes or they can be periodically weighed, either by physically 
removing them from the ground and weighing them or by placing them on a buried scale. Weighing lysimeters are the most accurate systems for obtaining the complete water balance of a soil volume (i.e., direct measurements of evapotranspiration, storage change, and drainage). Nonweighing lysimeters can only measure evapotranspiration and water storage changes indirectly. Some nonweighing lysimeters can be specially designed to measure drainage by using under-drain collection systems or suction cup-vacuum systems. Examples of the former are the Buried-Waste Test Facility caissons located near the Hanford 300-N Area burial ground, while examples of the latter are the 18-m-deep lysimeters located near the 200-E Area.

Weighing lysimeters are capable of directly measuring evapotranspiration and changes in water storage, as well as of drainage and precipitation; hence, in general, they have features that make them attractive for use in testing/ validating unsaturated water flow and water balance models. Both nonweighing and weighing lysimeters can also be used to measure solute transport in the unsaturated zone. Table 1 lists key advantages and disadvantages of using lysimeters for measuring various hydrologic processes.

At Hanford, the primary advantage of lysimetry is the direct measurement of drainage. However, lysimeter experiments should be designed so that as many components of the water balance can be measured as is practical. The use of relatively shallow weighing lysimeters in combination with deeper nonweighing lysimeters equipped with drainage collection devices appears to be an appropriate way to assess the complete water balance at a given site. 
TABLE 1. Lysimeter Features Useful for Studies of Water Balance and Solute Transport in Unsaturated Zones

\begin{tabular}{|c|c|c|}
\hline $\begin{array}{l}\text { Hydrologic } \\
\text { Process }\end{array}$ & $\begin{array}{l}\text { Advantage } \\
\text { of Lysimeter }\end{array}$ & $\begin{array}{l}\text { Di sadvantage } \\
\text { of Lysimeter }\end{array}$ \\
\hline $\begin{array}{l}\text { Water content } \\
\text { storage }\end{array}$ & $\begin{array}{l}\text { Establishes fixed volume } \\
\text { for storage and fixed area } \\
\text { for rain input } \\
\text { Weighing lysimeter best } \\
\text { measure of storage }\end{array}$ & $\begin{array}{l}\text { Accurate water contents are } \\
\text { difficult to measure at } \\
\text { lysimeter boundaries } \\
\text { Accumulation of water at } \\
\text { lysimeter bottom may perturb } \\
\text { water contents with respect to } \\
\text { natural conditions } \\
\text { May perturb runon/runoff } \\
\text { properties }\end{array}$ \\
\hline Drainage & $\begin{array}{l}\text { Establishes fixed volume } \\
\text { Eliminates lateral flow } \\
\text { into a fixed volume }\end{array}$ & $\begin{array}{l}\text { Outflow (drainage) boundary } \\
\text { condition generally different } \\
\text { from that of field. Perched } \\
\text { water table can be created, } \\
\text { causing underestimation of } \\
\text { drainage. }\end{array}$ \\
\hline Evaporation & $\begin{array}{l}\text { Establishes fixed volume } \\
\text { Weighing lysimeter is only } \\
\text { direct way to measure } \\
\text { evaporation }\end{array}$ & $\begin{array}{l}\text { Thermal perturbation may change } \\
\text { natural evaporation rate }\end{array}$ \\
\hline Transpiration & $\begin{array}{l}\text { Establishes fixed volume } \\
\text { Contains root systems } \\
\text { Only direct way to } \\
\text { measure transpiration }\end{array}$ & $\begin{array}{l}\text { May cause plant growth and root } \\
\text { densities to differ from those } \\
\text { of natural systems } \\
\text { Duplication of natural } \\
\text { population and plant densities } \\
\text { is difficult }\end{array}$ \\
\hline Solute transport & $\begin{array}{l}\text { Contains solute plume and } \\
\text { enhances mass balance } \\
\text { One-dimensional flow }\end{array}$ & $\begin{array}{l}\text { Real system may have two- or } \\
\text { three-dimensional flow } \\
\text { May restrict dispersion }\end{array}$ \\
\hline
\end{tabular}




\section{PAST AND PRESENT LYSIMETER FACILITIES AT HANFORD}

Lysimeters have been used in one form or another at the Hanford Site since the early 1970s. Six major lysimeter facilities, consisting of more than 50 individual lysimeters, have been built throughout the 200 and 300 Areas and the ALE Reserve. Four of the facilities are still being maintained and monitored at some level. The purposes of the lysimeters include the study of root penetration through physical barriers such as asphalt and concrete, the study of deep drainage and recharge, and the analysis of the leaching rates of solid waste forms. Some facilities have been designed to collect data at a level compatible with model verification/validation studies, while others have been designed simply to demonstrate the presence or absence of some process such as deep drainage or radionuclide transport. A summary of the six major facilities, including their location, the number of lysimeters at each, their primary purpose, and their current status, is shown in Table 2. Figure 2 shows the location of the facilities on the Hanford Site. A description of each facility, including its design, the level of instrumentation and monitoring available, and information obtained from the facility to date, follows.

\section{LYSIMETER FACILITY 1: 200-E AREA ROCKWELL LYSIMETERS}

The first lysimeters constructed at Hanford were the 200-E Area Rockwell lysimeters. The lysimeters have been described in detail by Hsieh, Brownell and Reisenauer (1973) and by Brownell et al. (1975) and were reviewed recently by Gee and Heller (1985). A schematic diagram of the 200-E Area facility is shown in Figure 3. At this facility are two lysimeters, each approximately $18.0 \mathrm{~m}$ deep and $3 \mathrm{~m}$ in diameter, filled with a uniform sandy soil.

The primary objective of the lysimeter facility was to address the problem of deep drainage (i.e., recharge) in the unsaturated zone at Hanford. The approach was to construct two lysimeters, one with a closed bottom sealed with a concrete pad and an aluminum plate, and one completely open at the bottom (Figure 3). It was reasoned that if deep drainage were occurring in the 200 Area plateau, water should accumulate in the bottom of the closed-bottom 
TABLE 2. Lysimeter Facilities at the Hanford Site

\begin{tabular}{|c|c|c|c|c|c|c|c|}
\hline $\begin{array}{l}\text { Location } \\
\text { Designation }\end{array}$ & Location & $\begin{array}{c}\text { Installation } \\
\text { Date }\end{array}$ & Size/Type & Number & Purpose & Reference & Status \\
\hline 1 & $\begin{array}{l}\text { 200-E Area } \\
\text { (Rockwell Hanford } \\
\text { Operations } \\
\text { lysimeters) }\end{array}$ & $1971 / 72$ & 18-m-deep & 2 & - Water balance & $\begin{array}{l}\text { Brownell } \\
\text { et al. } 1975\end{array}$ & $50 \%$ maintained \\
\hline 2 & $\begin{array}{l}200-W \text { Area } \\
\text { (S-10 Culverts) }\end{array}$ & 1975 & 2-m-deep & 16 & Root penetration & $\begin{array}{l}\text { Kirkham and } \\
\text { Cline } 1982\end{array}$ & $\begin{array}{l}50 \% \text { undisturbed but } \\
\text { not actively } \\
\text { maintained }\end{array}$ \\
\hline$\varpi$ & $\begin{array}{l}\text { 300-N Area } \\
\text { (Buried-Waste } \\
\text { Test Facility) }\end{array}$ & 1978 & 8-m-deep & 6 & $\begin{array}{l}\text { Water balance } \\
\text { (bare soil) }\end{array}$ & $\begin{array}{l}\text { Phtllips } \\
\text { et al. } 1979\end{array}$ & Active \\
\hline & $\begin{array}{l}\text { 300-N Area } \\
\text { (Buried-Waste } \\
\text { Test Facility) }\end{array}$ & $1978 / 79$ & $\begin{array}{l}\text { Plat form-scale } \\
\text { weighing } \\
(1.5-m \times 1.5-m)\end{array}$ & 2 & $\begin{array}{l}\text { - Water balance } \\
\text { (bare soil and } \\
\text { vegetated) }\end{array}$ & $\begin{array}{l}\text { Kirkham, fiee } \\
\text { and Jones } \\
1984\end{array}$ & Active \\
\hline 4 & $\begin{array}{l}\text { 300-N Area } \\
\text { (Commercial-Waste } \\
\text { Test Facility) }\end{array}$ & $1983 / 84$ & 3-m-deep & 10 & $\begin{array}{l}\text { Water balance } \\
\text { and leaching } \\
\quad \text { (bare soil) }\end{array}$ & $\begin{array}{l}\text { Walter, Graham } \\
\text { and Gee } 1984\end{array}$ & Active \\
\hline 5 & $\begin{array}{l}300-N \text { Area } \\
\text { (Grout Waste } \\
\text { Test Facility) }\end{array}$ & 1985 & 8-m-deep & 2 & $\begin{aligned} \text { - Water balance } \\
\text { and leaching } \\
\quad \text { (bare soil) }\end{aligned}$ & Treat 1985 & Active \\
\hline 6 & $\begin{array}{l}600 \text { Area } \\
\text { (ALE Reserve) }\end{array}$ & 1971 & $\begin{array}{l}\text { Small-scale } \\
\text { weighing } \\
\text { (0.1-m-dia } \times \\
1-m-\text { deep })\end{array}$ & (Numerous & $\begin{array}{l}\text { s) Water balance } \\
\text { and radionu- } \\
\text { clide transport } \\
\text { (vegetated) }\end{array}$ & Hinds 1973 & Inactive \\
\hline
\end{tabular}




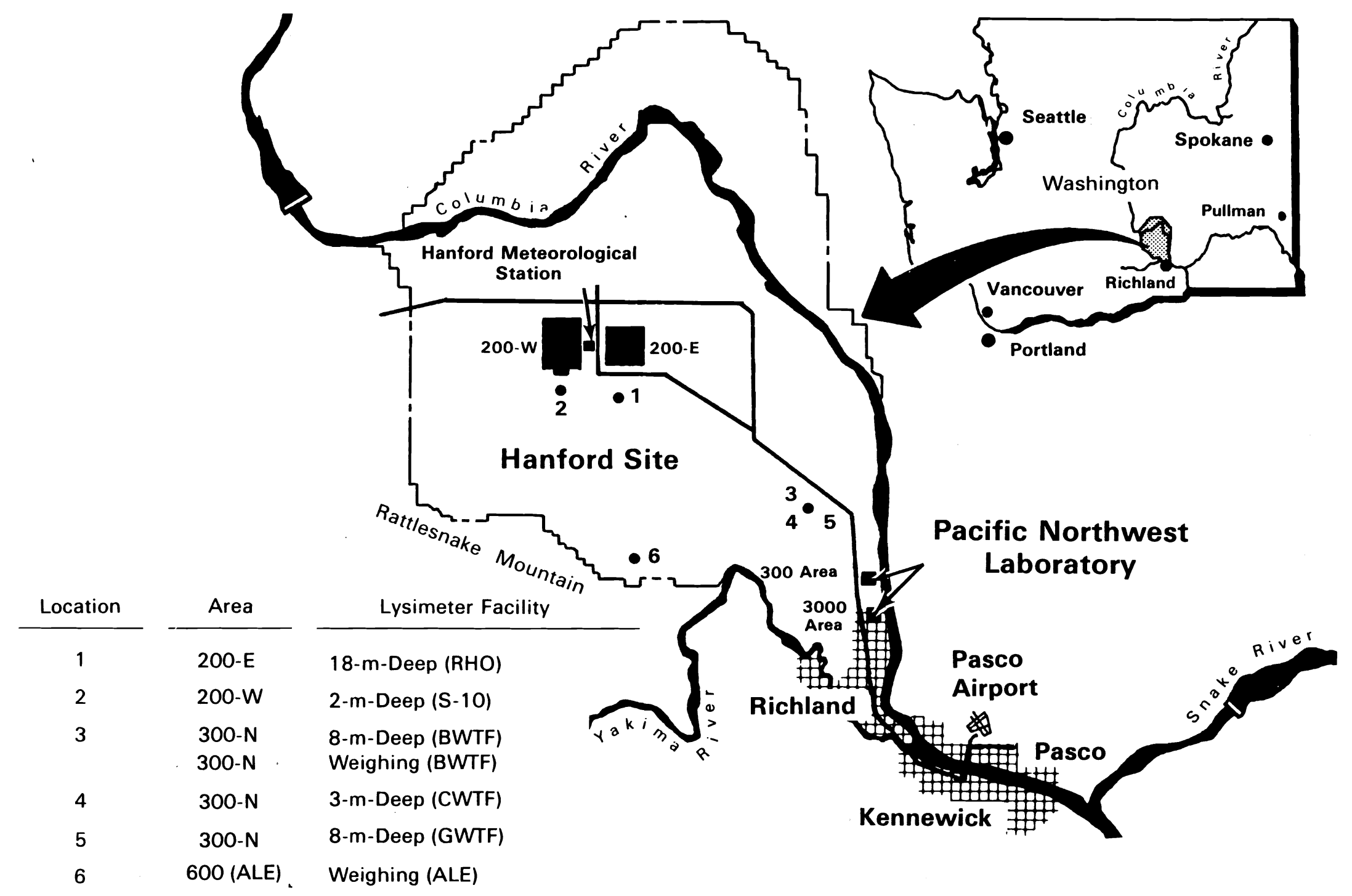

FIGURE 2. Locations of Lysimeter Facilities at the Hanford Site 


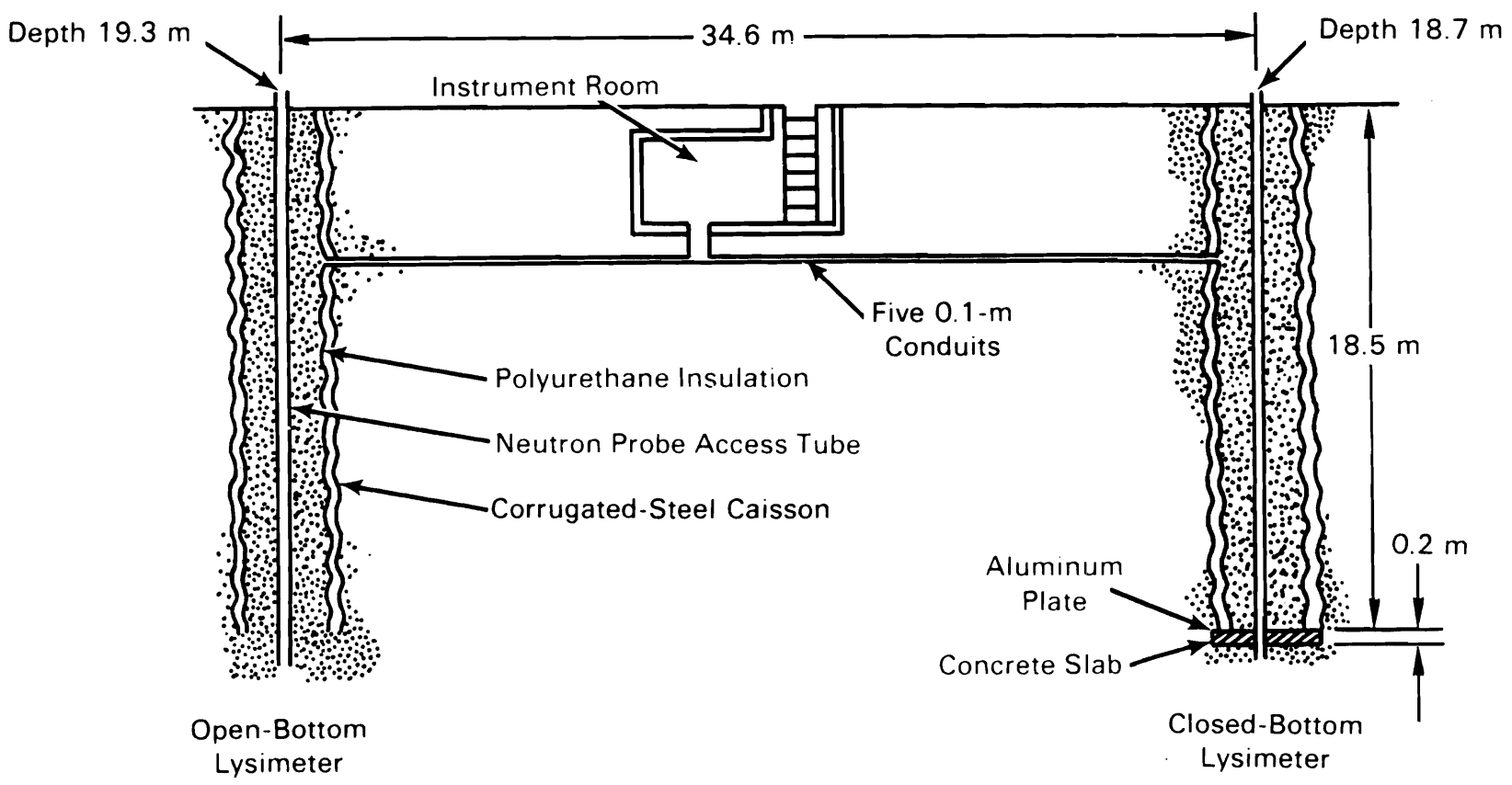

FIGURE 3. Schematic Diagram of 18-m-Deep Caisson Lysimeters in the 200-E Area (After Brownell et al. 1975)

lysimeter. It was hoped that the presence or absence of an accumulation of water would conclusively demonstrate or refute the recharge question.

A secondary objective was to monitor several soil properties, including soil temperature, soil water potential, water content, and pore-air pressure. These data were to support the development of a detailed water flow model capable of predicting arid-zone water balance. However, various problems that were encountered during the installation and early monitoring of these lysimeters have prevented the measurement of any quantity except soil water content.

The moisture content of the soil has been monitored with neutron probes since lysimeter installation in late 1970 and early 1971. Although the top $6 \mathrm{~m}$ of one lysimeter had a higher initial water content than the other, neither lysimeter has shown measurable changes in water content below about the 6-m depth. This lack of accumulation of water at lower depths over time has been interpreted by some authors as proof that no deep drainage is occurring (Brownell et al. 1975; Last, Easley and Brown 1976). Jones (1978) reviewed the data from these two lysimeters for the period from installation in $1971 / 2$ 
through 1977. He confirmed that, within the detection limits of the neutron probe, the water content at depth was not changing and there was no observable accumulation of water in either lysimeter. However, he interpreted the uniform water content distribution that persists in this homogeneous soil as an indication of a downward flow of water caused by gravity-induced drainage (unit gradient flow, as described previously). Jones further suggested that although no water content change was detected, a recharge rate of as much as $0.5 \mathrm{~cm} / \mathrm{yr}$ could easily have gone undetected in these nonweighing uniform lysimeters over the 6-year test period.

No data on the 200-E Area 18-m-deep lysimeters have been published since the report of Jones in 1978. Recent correspondence with Rockwell personnel indicates that additional neutron probe data at this site are available. The open-bottom lysimeter was excavated to a depth of about $6 \mathrm{~m}$ in the spring of 1983 , so there is no continuity of record on this lysimeter. However, the closed-bottom lysimeter has been monitored on about a 6 -month interval since the fall of 1983. The recent data from the closed-bottom lysimeter continue to show that the water content of the lysimeter soil below a depth of about $6 \mathrm{~m}$ has apparently changed little.

The major problem with the 200-E Area lysimeter data is the lack of direct measurement of deep drainage. The lysimeters do not have any collection system for drainage water; therefore, drainage must be estimated indirectly from water content measurements. Unfortunately, the data provide two conflicting conclusions. On the one hand, no observable accumulation of water has been observed, which would indicate either no or extremely low rates of drainage. On the other hand, the uniform water content distribution is consistent with unit gradient, deep drainage. Another 1 imitation of the data set is the question of plant-water use. The lysimeters were originally intended to be kept unvegetated, but cheatgrass and Russian thistle were allowed to invade the lysimeters at least for the period of 1977 to 1982 (see Gee and Heller 1985). The resulting uncertainty about the surface conditions will make any modeling of the data difficult. The measurements taken in the closed-bottom lysimeter should be considered valuable, but at the present time they are an ambiguous and 
unresolved data set in terms of predicting recharge rates. Core sampling of the entire soil profile would be one way to help resolve the uncertainty of the neutron probe data.

\section{LYSIMETER FACILITY 2: BIOINTRUSION LYSIMETERS}

In 1975, a study was initiated by PNL to examine the effectiveness of various layered materials in preventing plant and animal intrusion into waste sites (Cline, Gano and Rogers 1980; Kirkham and Cline 1982). Lysimeters and a large trench were used to test for biointrusion. Several barrier systems, including soil layers containing loose rock, asphalt emulsion, and soil spiked with root toxin, were tested. Root penetration was detected by measuring the plant uptake of tracers placed in the soil below the barrier. Animal intrusion was studied in the large trench by observing ant and pocket mouse tunnels after excavation.

A total of 28 lysimeters (1.2-m-dia by 2.4-m-deep caissons) were filled with soil containing various barrier systems (see Figure 4). The lysimeters were constructed near the 216-S-10 ditch just south of the 200-W Area. The lysimeters were open at the bottom. No information on hydraulic properties is available for the test soil, but texturally the soil is similar to the 200 Area deep lysimeter soil (coarse textured, well drained). Twelve of the lysimeters were destructively sampled. The remaining 16 lysimeters are still in place but have not been actively maintained. These units could be used in the future to test the effectiveness of barriers to both plant and water intrusion.

Biointrusion tests using layered materials may be necessary when final designs are developed for protective barrier systems. Small lysimeters similar to the design used by Hinds (1973) and Cline, Gano and Rogers (1980) would be useful in assessing barrier performance, but additional measurements of water content and water storage in the lysimeters would be needed to quantify the effects of water movement on biointrusion. The 16 remaining large lysimeters may be useful for evaluating the relatively long-term (10-year) response of a barrier system to water infiltration and drainage. 

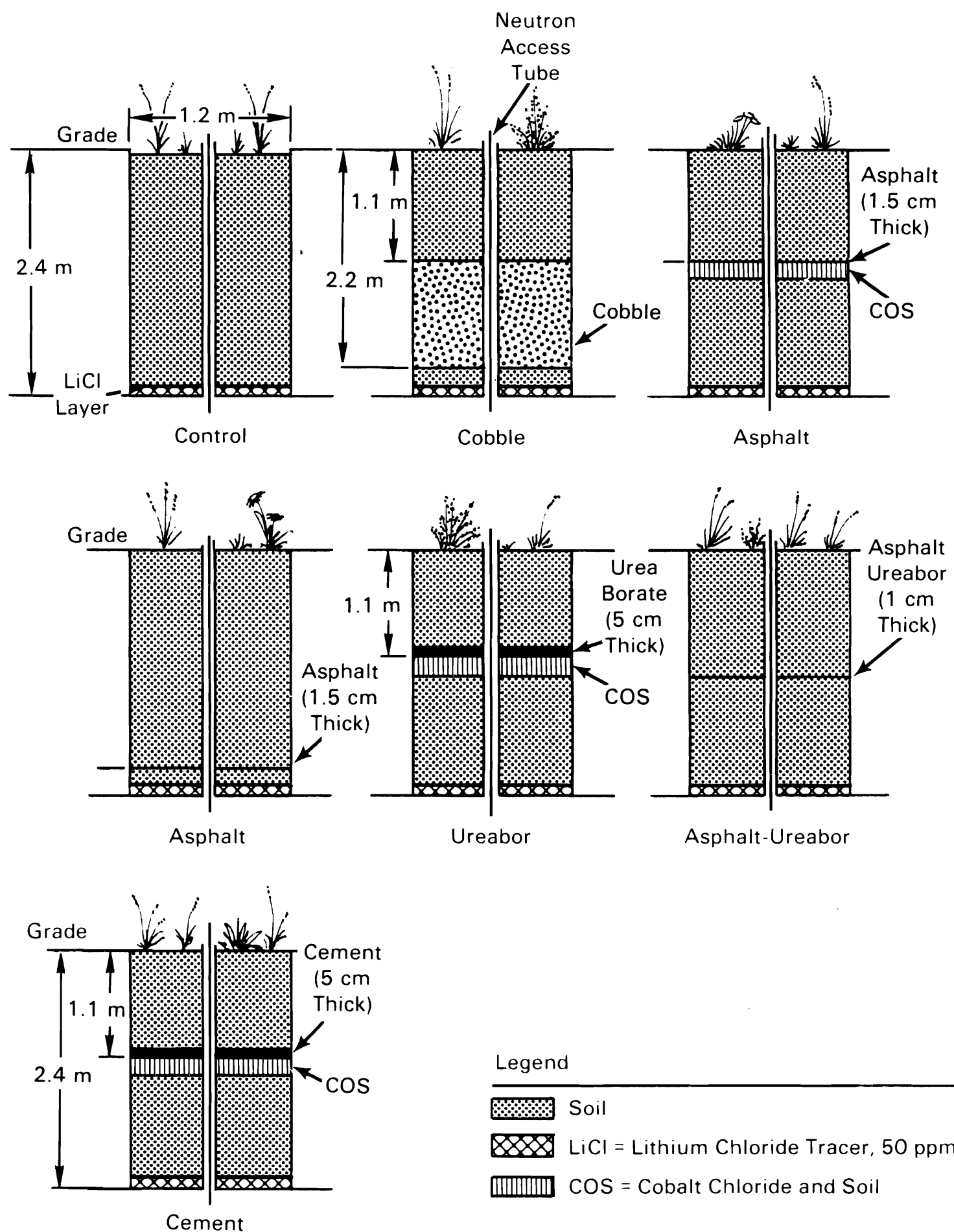

Legend

Soil

LiCl = Lithium Chloride Tracer, 50 ppm Li

盂盂血 $\operatorname{los}=$ Cobalt Chloride and Soil

FIGURE 4. Schematic Diagram of Biointrusion Lysimeters in the 200-W Area 


\section{LYSIMETER FACILITY 3: BURIED-WASTE TEST FACILITY (BWTF) LYSIMETERS}

The lysimeter facility at the BWTF in the 300 Area was constructed in the spring of 1978 (Phillips et al. 1979). It is described in detail in the Phillips report, and data from the lysimeters are presented and analyzed in two subsequent reports (Jones and Gee 1984; Jones, Campbell and Gee 1984). A recent review of the facility is given by Gee and Heller (1985).

The facility consists of eight individual lysimeters, six nonweighing and two weighing lysimeters (see Figure 5). The six nonweighing lysimeters are $7.6 \mathrm{~m}$ deep; two of them are $2.7 \mathrm{~m}$ in diameter and the other four are $0.6 \mathrm{~m}$ in diameter. The two weighing lysimeters (one of which was added in 1979) are each built out of rectangular box, $1.5 \mathrm{~m}$ on a side. These lysimeters are described in detail by Kirkham, Gee and Jones (1984). Figure 6 shows a cross section of one weighing lysimeter, complete with platform scale and drainage collection system (suction candles). An important feature of the two weighing lysimeters is that they can be continuously monitored, thus providing changes in storage estimates on time scales ranging from hours to years. The estimated precision of measurement for changes in storage and drainage is about $\pm 0.1 \mathrm{~cm} / \mathrm{yr}$. Four of the lysimeters (one large-diameter, two small-diameter, and one weighing lysimeter) were irrigated intermittently over a period of about 2 years (1979 to 1981).

In addition to lysimeter data on water storage and drainage, additional data including extensive soil characterization (Cass, Campbell and Jones 1981 , 1984) and meteorological information were collected to support model development and evaluation. Radionuclide transport studies were also performed (Jones et al. 1983). Recently, one of the weighing lysimeters was planted to cheatgrass and transpiration measurements were started (Gee and Kirkham 1984).

The data collected at the BWTF differ from those collected by the 200-E Area lysimeter in that drainage water is collected and measured directly in three of the lysimeters (two weighing lysimeters and one nonweighing lysimeter) (see Figure 5). Water content profiles have been monitored with neutron probes in a manner similar to that used in the 200-E Area Rockwell lysimeters. The upper 1 to $2 \mathrm{~m}$ show seasonal variations, and the middle and lower depths ( 3 to $5 \mathrm{~m}$ ) show the same uniform water content profile with depth as has been 


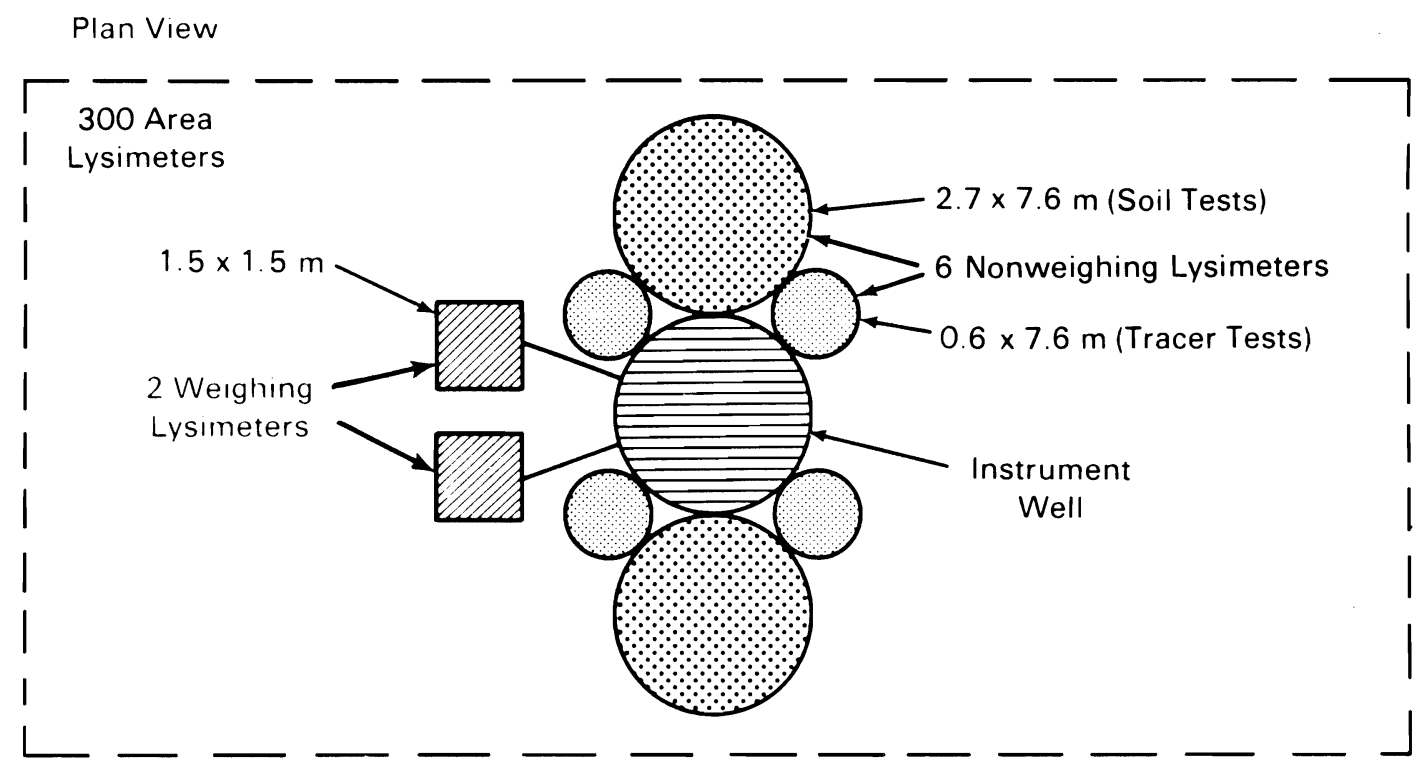

Cross Section

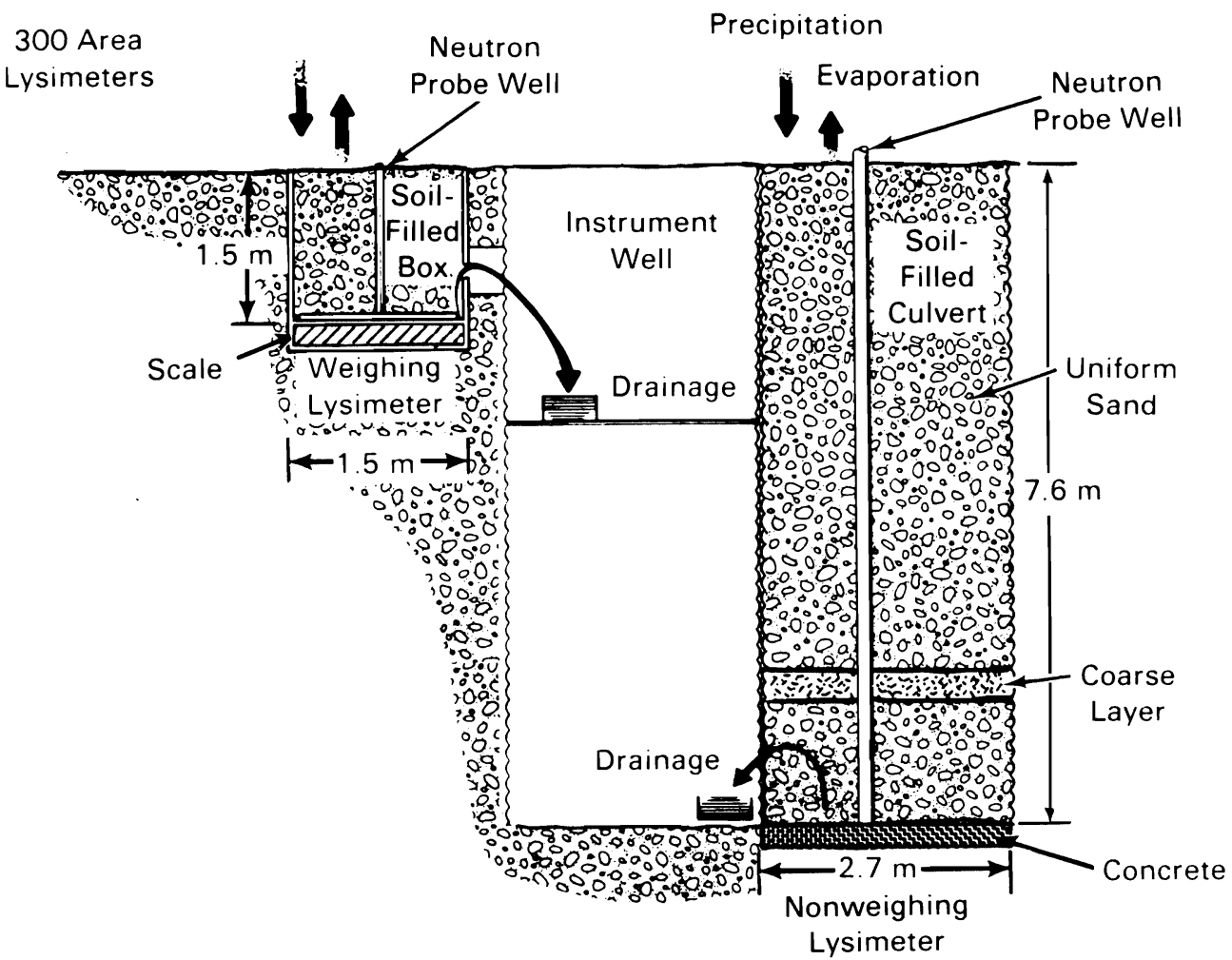

FIGURE 5. Schematic Diagram of the Lysimeters at the Buried-Waste Test Facility Site in the 300 Area 


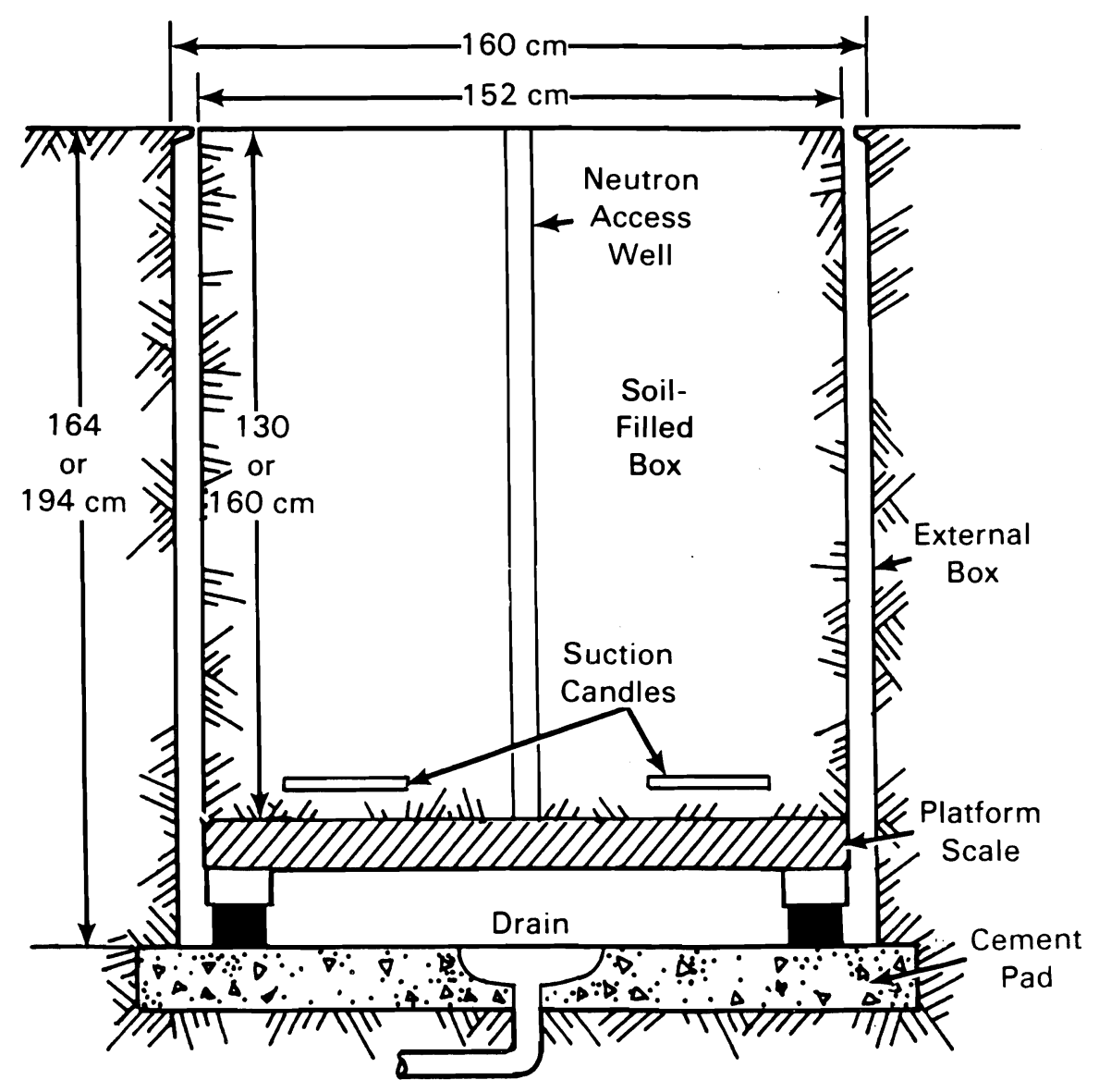

FIGURE 6. Schematic Diagram of Weighing Lysimeters at the Buried-Waste Test Facility Site in the 300 Area (After Kirkham, Gee and Jones 1984)

observed in the Rockwell lysimeters. A layer of coarse sand located in the nonweighing lysimeter just below the $6-m$ depth causes a nonuniformity in the water content data due to the textural and lithologic discontinuity it represents. This layer has been used as a check on neutron probe position as well as a means to observe the effects of layered soil on drainage characteristics. The only apparent effect on drainage rate was a slight delay caused by an increase ( 2 to 3 vol\%) in water above the layer before drainage occurred.

In contrast to the 200 Area data, the 300 Area data show an increase in water content over time at depth in the lysimeter, and drainage water is being 
collected from the bottom. The amount of drainage water extracted from a freedrainage collection system at a depth of over $7 \mathrm{~m}$ has exceeded $5 \mathrm{~cm} / \mathrm{yr}$ over the 1 ast 3 years. It should be noted that precipitation in the past 5 years (1980 through 1984) has been above normal with the 1983 maximum of $28.1 \mathrm{~cm}$ exceeding the long-term average by $12 \mathrm{~cm}$. The effect of the above-normal precipitation on measured drainage rates needs to be considered in any predictive model of the recharge at this site.

A preliminary attempt to model the water balance of the BWTF was completed in 1984 (Jones, Campbell and Gee 1984). The results were encouraging; the model predictions tracked well with the measured storage and drainage data. However, the results were considered only preliminary because of uncertainties in the BWTF data base. Since the first report was completed, the BWTF data base has been enhanced by 2 additional years of data and improved from a quality assurance point of view. A detailed neutron probe calibration has been completed for the currently available neutron probe, and cross-calibration has been completed on other probes used previously during the past 6 years, so that a nearly continuous data set has been obtained. A more conclusive modeling effort is planned using the improved data set and will be completed in fiscal year 1986.

Limitations to the use of lysimetry data for modeling involve the continuity of onsite meteorological data. For the preliminary modeling exercise, data from the 200 Area meteorological station were used to supplement the BWTF data base. Instrumentation and data collection experience gained during the lifetime of both the 200 Area and BWTF lysimeter projects have led to better and more reliable systems being implemented.

\section{LYSIMETER FACILITY 4: COMMERCIAL-WASTE TEST FACILITY (CWTF) LYSIMETERS}

Figure 7 is a schematic diagram of the Commercial-Waste Test Facility in the 300 Area. This facility, adjacent to the BWTF site, was installed in late 1983 and early 1984 and is described in detail by Walter, Graham and Gee (1984). The facility consists of 10 lysimeters made of sealed-bottom vertical containers (caissons) each of which is $1.8 \mathrm{~m}$ in diameter and $3 \mathrm{~m}$ deep. The lysimeters are filled with soil materials very similar to the BWTF lysimeter 


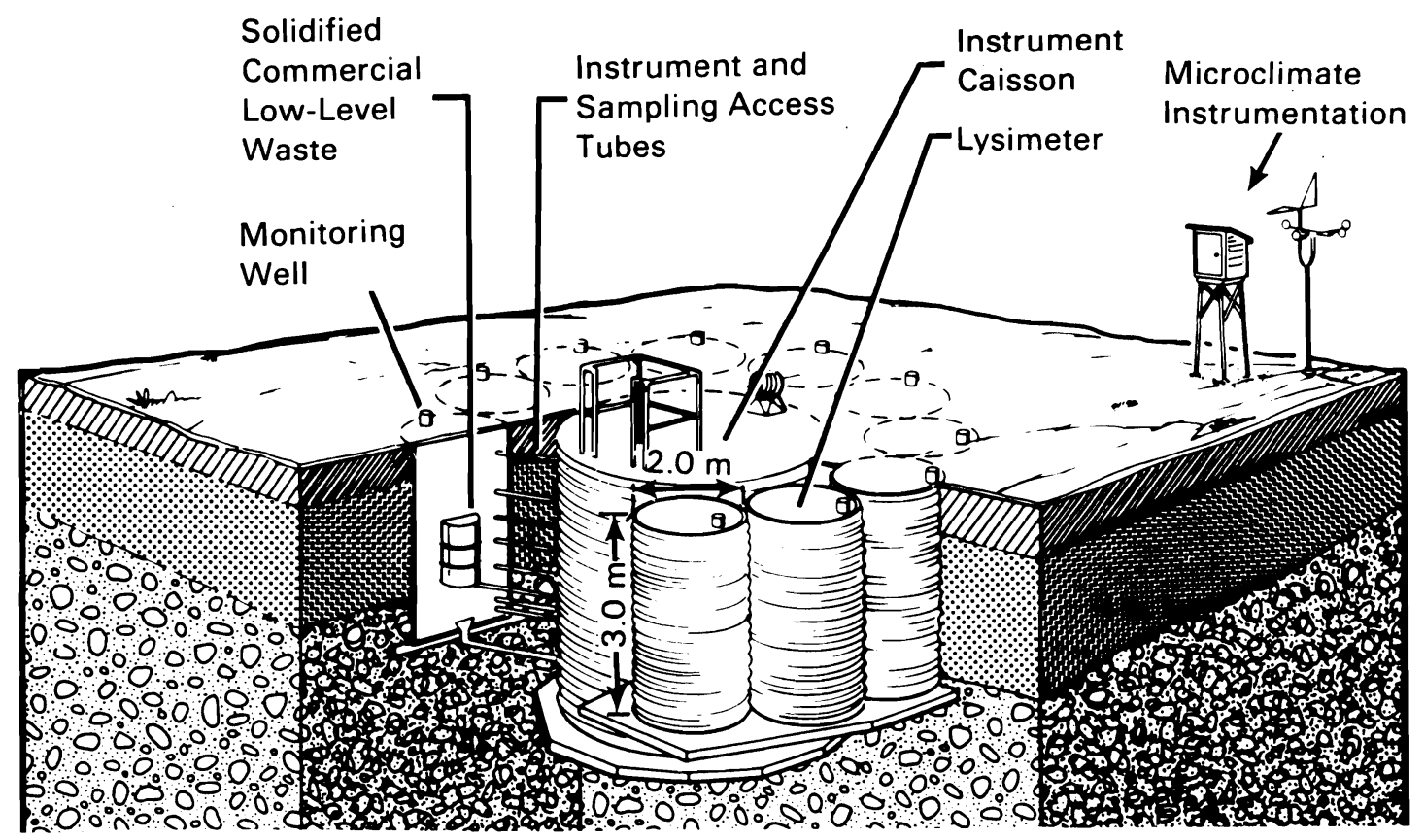

FIGURE 7. Schematic Diagram of Lysimeters at the Commercial-Waste Test Facility in the 300 Area (After Walter, Graham and Gee 1984)

soils in texture and hydrologic properties (sandy texture and readily drained). Each lysimeter has an under-drain collection device as well as a porous cupvacuum system for the removal of soil water so that either free drainage or controlled-pressure (suction) head can be maintained at the bottom of the lysimeter. Each lysimeter contains a 208-L (55-gal) volume of commercial waste that has been solidified with either bitumen, polymer, or cement. The purpose of the facility is to evaluate the leaching of solidified low-level waste in an arid environment. Some detailed leaching chemistry studies are under way both in the laboratory and at this facility to assess the source term associated with solidified commercial waste. The hydrology and the effect of stochastically derived rainfall input are to be assessed in model simulations of the facility. Because the facility is relatively new, no drainage data have been published to date. This study is funded by the U.S. Department of Energy's National Low-Level Waste Program and is scheduled to continue for at least another 3 years. 


\section{LYSIMETER FACILITY 5: GROUT WASTE TEST FACILITY (GWTF) LYSIMETERS}

A schematic diagram of the Grout Waste Test Facility in the 300 Area is shown in Figure 8. These lysimeters are designed to evaluate leaching of grout-treated waste under field conditions (Treat 1985). Four lysimeters have been designed and are presently in various stages of construction. One lysimeter, $2 \mathrm{~m}$ in diameter and $8.2 \mathrm{~m}$ deep, has been filled with soil and contains numerous small samples of grout-treated Hanford facilities waste. This lysimeter was backfilled with layers of coarse- and fine-textured soil materials taken from the AP tank farm in the 200 Area. The lysimeter is instrumented with porous-Teflon ${ }^{\circledR}$ suction samplers for collecting water from the unsaturated zone. A central access tube provides a means to monitor the moisture profile using downwell neutron probes. The bottom of the lysimeter is sealed, and drainage water will be collected with a vacuum system. One additional lysimeter will be filled and instrumented in September 1985. The resolution of these lysimeters in measuring water balance components is comparable to that of the BWTF nonweighing lysimeters.

\section{LYSIMETER FACILITY 6: ALE RESERVE LYSIMETERS}

Figure 9 is a schematic diagram of a small weighing lysimeter used for water balance and radionuclide transport studies. This type of lysimeter has been used rather extensively on the ALE Reserve for a number of years (Hinds 1973; Cline, Gano and Rogers 1980). The lysimeters are typically about $13 \mathrm{~cm}$ in diameter with lengths of $100 \mathrm{~cm}$ or less, made of plastic, and inexpensive to build (a few dollars for materials). Evapotranspiration rates are determined directly from weight changes obtained by removing the lysimeters from the ground and weighing them on a scale. Root growth and contaminant uptake patterns can be obtained by destructively sampling the lysimeters (Cline, Gano and Rogers 1980). The only quantitative data relating rooting density and actual evapotranspiration for cheatgrass at Hanford were collected using this type of lysimeter (Hinds 1973). These data have been used to generate empirical relationships to model evapotranspiration from cheatgrass (Gee and Simmons 1979). 


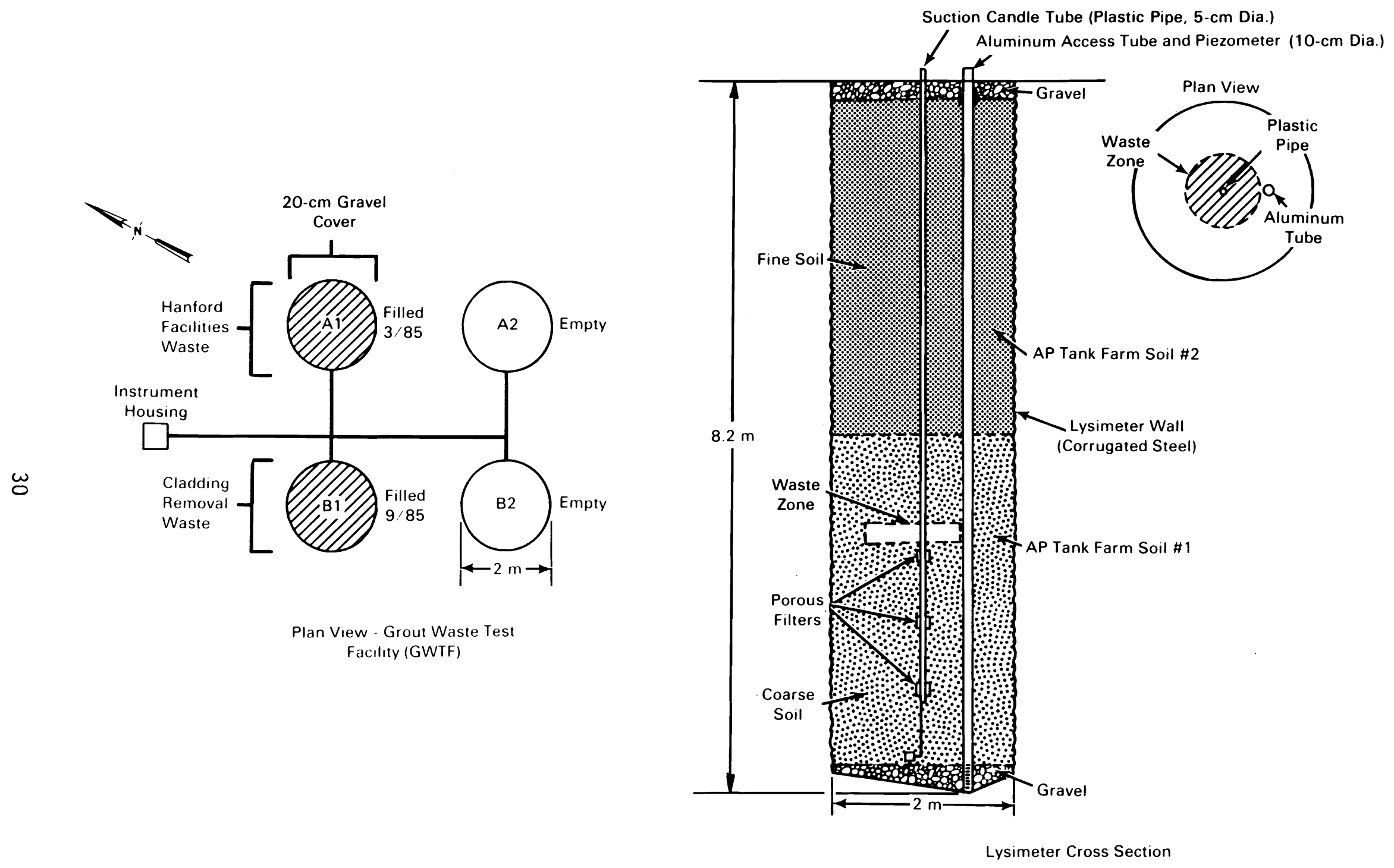

FIGURE 8. Schematic Diagram of Lysimeters at the Grout Waste Test Facility in the 300 Area 


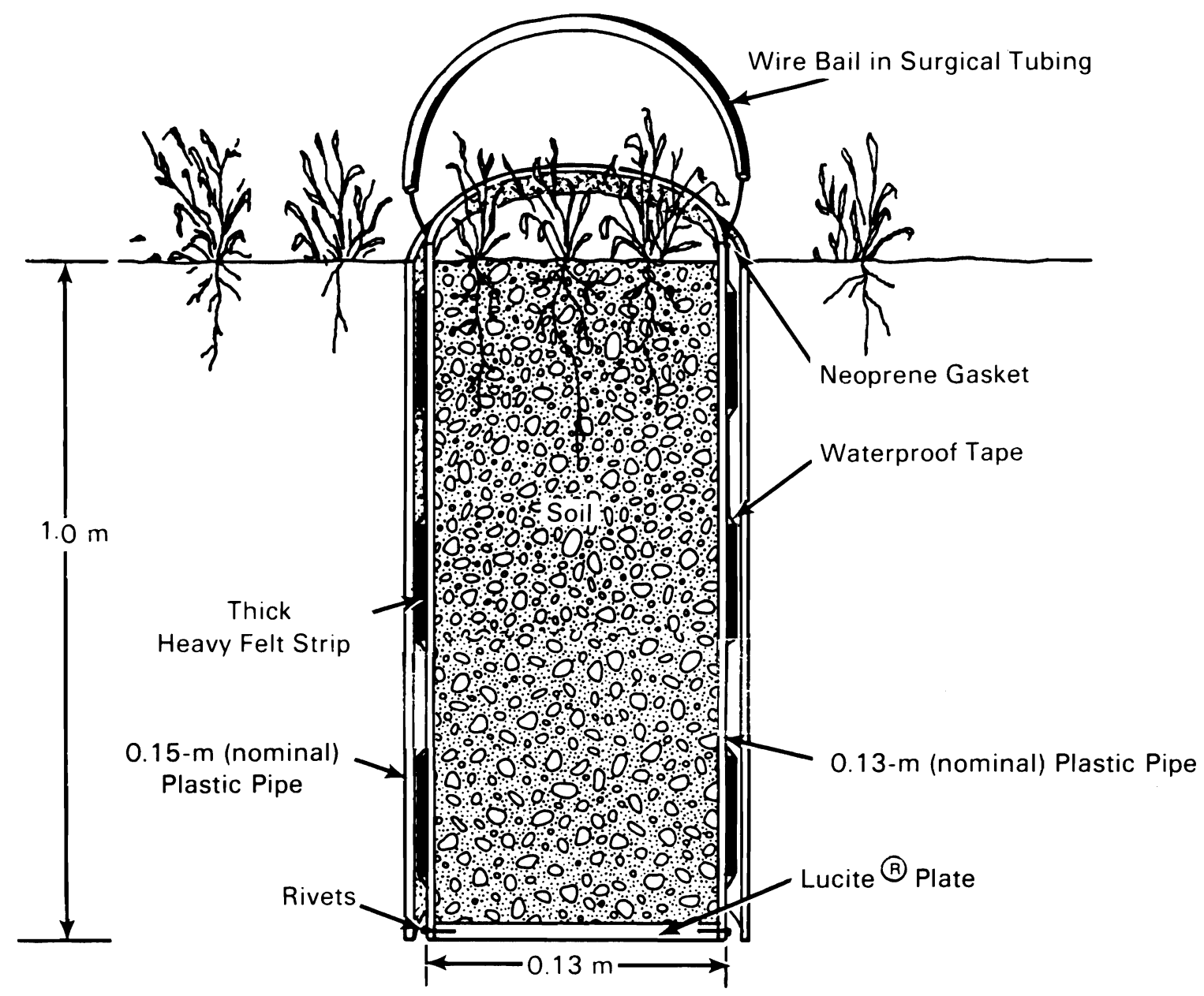

(B) Lucite is a trademark of E. I. du Pont de Nemours Company, Wilmington, Del aware.

FIGURE 9. Schematic Diagram of Small Weighing Lysimeters at the Arid Lands Ecology Reserve (After Hinds 1973)

Disadvantages of these units include their size (small diameter and shallow depth) and the fact that normally they are sealed at the bottom, so no drainage is measured. It is not clear whether data of this type, generated in small lysimeters, are valid for large-scale field simulations. The data are important, however, since no other data on transpiration rates at the Hanford Site are available at present. The precision of these devices is related 
directly to measured weight changes. Errors in evapotranspiration and water storage changes are estimated to be about $\pm 0.6 \mathrm{~cm} / \mathrm{yr}$ or less (Hinds 1973).

\section{SECTION SUMMARY}

Lysimeters have been used at Hanford since the 1970s. The motivation for using lysimeters has varied from facility to facility, and therefore the construction and instrumentation of the facilities are different. Table 3 summarizes how each facility is equipped to measure or calculate each component of the water balance.

The table shows that the two main areas of difference are in whether water storage is measured directly by the use of scales or inferred from neutron probe measurements, and whether drainage is measured directly by collecting water at the bottom of the lysimeter or calculated from neutron probe data. The quantities calculated from neutron probe measurements are the least accurate; those calculated by weight are the most accurate.

It is safe to say that no lysimeter facility built to date has had an optimum design, nor has any facility been adequately supported financially to optimize the quality and continuity of data collected. However, each facility has provided useful data that should not be disregarded. The development of a complete understanding of unsaturated flow at Hanford will rely on these historical data bases as well as on future efforts, and any understanding developed cannot be complete until the data from each experiment are explained at least qualitatively. 
TABLE 3. Measurement Capabilities of Hanford Lysimeter Facilities

\begin{tabular}{|c|c|c|c|c|c|c|c|c|c|c|}
\hline $\begin{array}{c}\text { Site } \\
\text { Number }\end{array}$ & $\begin{array}{l}\text { Lysimeter } \\
\text { Facility } \\
\end{array}$ & $\begin{array}{c}\text { Water } \\
\text { Content } \\
\end{array}$ & Storage & Evapotranspiration & Drainage & & Snion & Runoff $(b)$ & $\begin{array}{c}\text { Soil } \\
\text { Temperature } \\
\end{array}$ & $\begin{array}{c}\text { Source of } \\
\text { Weather Data }\end{array}$ \\
\hline 1. & $\begin{array}{l}\text { 200-E Area } \\
\text { (Rockwell) }\end{array}$ & $N P(c)$ & $\begin{array}{l}\text { Calculations } \\
\text { from NP }\end{array}$ & $\begin{array}{l}\text { Calculations } \\
\text { from NP }\end{array}$ & $\begin{array}{l}\text { Calculations } \\
\text { from NP }\end{array}$ & mis $(d)$ & None & None & No & HMS $(8 \mathrm{~km})^{(\mathrm{d})}$ \\
\hline 2. & $\begin{array}{l}200-W \text { Area } \\
\text { (S-10 culverts) }\end{array}$ & NP & $\begin{array}{l}\text { Calculations } \\
\text { from NP }\end{array}$ & $\begin{array}{l}\text { Calculations } \\
\text { from NP }\end{array}$ & $\begin{array}{l}\text { Calculations } \\
\text { from NP }\end{array}$ & HMS & None & None & No & HMS $(5 \mathrm{~km})$ \\
\hline \multirow[t]{2}{*}{3.} & $\begin{array}{l}300-N \text { Area } \\
\text { (BWTF deep } \\
\text { caissons) }\end{array}$ & $\begin{array}{l}\text { NP same } \\
\text { samples }\end{array}$ & $\begin{array}{l}\text { Calculations } \\
\text { from NP }\end{array}$ & $\begin{array}{l}\text { Calculations } \\
\text { from NP }\end{array}$ & Free drainage & Onsite & None & None & Yes & $\begin{array}{l}\text { Onsite and HitS } \\
(28 \mathrm{~km})\end{array}$ \\
\hline & $\begin{array}{l}\text { (BWTF weighing } \\
\text { iysimeters) }\end{array}$ & NP & $\begin{array}{l}\text { Calculations } \\
\text { from NP and } \\
\text { weight }\end{array}$ & $\begin{array}{l}\text { Calculations from } \\
\text { weight changes }\end{array}$ & Suction candles & Onsite & None & None & Yes & $\begin{array}{l}\text { Onsite and HMS } \\
(28 \mathrm{~km})\end{array}$ \\
\hline 4. & $\begin{array}{l}300-N \text { Area } \\
\text { (CWTF) }\end{array}$ & NP & $\begin{array}{l}\text { Calculations } \\
\text { from NP }\end{array}$ & $\begin{array}{l}\text { Calculations } \\
\text { from NP }\end{array}$ & $\begin{array}{l}\text { Suction candles } \\
\text { and free drainage }\end{array}$ & Onsite & None & None & Yes & Onsite \\
\hline 5. & $\begin{array}{l}300-N \text { Area } \\
(\text { GWTF })\end{array}$ & NP & $\begin{array}{l}\text { Calculations } \\
\text { from NP }\end{array}$ & $\begin{array}{l}\text { Calculations } \\
\text { from NP }\end{array}$ & Suction candles & Onsite & None & None & No & Onsite \\
\hline 6. & $\begin{array}{l}600 \text { Area } \\
\text { (ALE small- } \\
\text { scale weighing) }\end{array}$ & None & Weight & $\begin{array}{l}\text { Calculations from } \\
\text { weight changes }\end{array}$ & None & Onsite & None & None & No & Onsite \\
\hline
\end{tabular}

(a) No facility to date has been equipped to distinguish between snow and rain.

(b) All facilities to date have been designed for no runoff.

(c) Neutron Moisture Probe. 


\section{LYSIMETER NEEDS}

Lysimeters are key facilities needed to address the question of natural recharge at the Hanford Site. Water that is not recycled by root water uptake or evaporation moves through the subsurface soil to the water table as recharge. At present, there is no definitive answer as to how much deep drainage or recharge occurs at the waste disposal sites at Hanford. No direct measurement of recharge has been made at any of the waste sites. Recharge at Hanford will not be quantified until accurate measurements of evapotranspiration and water storage are made at several sites under a variety of soil and plant cover conditions. Additional lysimeters coupled with other measurements of water movement will be required to obtain this information.

The present estimates of water recharge to the water table at Hanford vary from 0 to as much as $8.5 \mathrm{~cm} / \mathrm{yr}$. Arid site recharge is known to vary depending on the interrelationships of soil, plant, and climatic variables. Table 4 lists the sources of data and types of measurements used to estimate recharge at Hanford and other arid sites. Clearly, recharge is not a simple function of climate (e.g., precipitation) alone and must be looked at on a site-specific basis. Possible reasons for the observed differences in recharge estimates at Hanford have been given in the previous sections.

Comprehensive model validation efforts and demonstration are the major reasons for continued work with lysimeters at Hanford. Predicting the longterm performance of burial sites will require that the unsaturated-flow model used to predict site water balance be calibrated with known evapotranspiration and drainage values from the burial site. Furthermore, the available water balance models need to be tested on data from the 200 and 300 Areas, and the ability to predict barrier performance must be demonstrated.

\section{MODEL EVALUATION}

We recommend that the isothermal model, UNSAT-H, be tested with the available 200-E Area and 300 Area data sets. We think it will be useful to simulate the 14-year moisture profile record for the closed-bottom Rockwell lysimeter. Although less information is available from the open-bottom lysimeter, it 
TABLE 4. Reported Estimates of Recharge at Selected Arid Sites

\begin{tabular}{|c|c|c|c|c|c|}
\hline Source & Location & Method & $\begin{array}{c}\text { Annual } \\
\text { Precipitation }(\mathrm{cm})\end{array}$ & 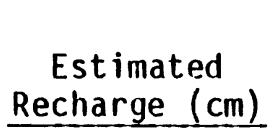 & $\begin{array}{c}\text { Recharge } \\
\text { as \% of } \\
\text { Precipitation }\end{array}$ \\
\hline $\begin{array}{l}\text { Enfield, Hsieh and } \\
\text { Warrick (1973) }\end{array}$ & $\begin{array}{l}\text { Hanford Site } \\
\text { (200 Area) }\end{array}$ & Darcy flux & 16 & $<1$ & $<6$ \\
\hline Brownell et al. (1975) & (200 Area) & Neutron probe & 16 & 0 & 0 \\
\hline Jones (1978) & (200 Area) & Neutron probe & 16 & $<0.5$ & $<3$ \\
\hline Gee and Kirkham (1984) & (300 Area) & $\begin{array}{l}\text { Neutron probe } \\
\text { and lysimeter }\end{array}$ & 28 & 6 & 21 \\
\hline $\begin{array}{l}\text { Dincer, Al-Mugrin and } \\
\text { Zimmerman (1974) }\end{array}$ & Saudia Arabia & Tritium tracer & 8 & 2 & 2.5 \\
\hline $\begin{array}{l}\text { Sammis, Evans and } \\
\text { Warrick (1982) }\end{array}$ & Arizona & $\begin{array}{l}\text { Darcy flux, } \\
\text { tritium, } \\
\text { temperature } \\
\text { profile }\end{array}$ & $100-150^{(a)}$ & 22 & 15 to 22 \\
\hline $\begin{array}{l}\text { Allison, Stone and } \\
\text { Hughes (1985) }\end{array}$ & Australia & Chloride tracer & 30 & 1.4 & 5 \\
\hline Stephens (1985) & New Mexico & Darcy flux & 18 & 4 & 22 \\
\hline $\begin{array}{l}\text { Narasimhan, White and } \\
\text { Tokunaga (1985) }\end{array}$ & Wyoming & Darcy flux & 22 & 2.1 & 10 \\
\hline
\end{tabular}

(a) Includes irrigation. 
should be possible to use the data from this lysimeter to verify estimates of hydraulic conductivity. In situ hydraulic conductivity tests could be performed in the open-bottom lysimeter to confirm hydraulic conductivity estimates used in previous model simulations.

Two attempts to simulate the water balance of the 200-E Area Rockwell lysimeters have been published (Baca, King and Norton 1978; Finlayson, Nelson and Baca 1978). Neither of these modeling studies addressed the effects of uncertainty in the moisture probe data nor attempted to predict moisture profiles beyond the span of a few months. The Finlayson report described in detail a comprehensive nonisothermal modeling procedure, but the simulation of the moisture profile indicates generally poor agreement with measured values. The Baca report showed nonisothermal model simulations of moisture profiles that appear to match neutron probe data reasonably well over a period of 4 months (December 1974 through March 1975). However, there is no published documentation for the Baca code, and a description of input parameters used for the simulations is lacking.

The need for a nonisothermal code to assess water balance in lysimeters has not actually been established. Several reports (Reisenauer et al. 1975; Jones 1978; Gee and Simmons 1979) estimate the effects of thermal gradients on recharge. These reports, specific to the Hanford Site, are in general agreement with the report by Ross (1984) which suggests that only if the recharge rate is less than $0.03 \mathrm{~cm} / \mathrm{yr}$ would thermally induced vapor flow significantly affect drainage. Water vapor flow rates caused by typical geothermal gradients are very smal1; at most, they could produce a recharge rate equivalent to less than $0.1 \mathrm{~cm} / \mathrm{yr}$. Numerous reports (Jackson et al. 1974; Kimball et al. 1976; Hamme1, Papendick and Campbel1 1981; Jones, Campbell and Gee 1984) indicate that nonisothermal models, as compared with isothermal models, do not necessarily improve water balance predictions for near-surface soils. Since no available data set contains sufficient heat and water profile data to adequately test a nonisothermal model over an extended time, we suggest that isothermal models be used to evaluate the water balance of the 200-E Area lysimeters. The use of UNSATH, an isothermal vapor flow model, is planned for fiscal year 1986 . 
It is imperative that present facilities in the 200 and 300 Areas be maintained. The 200-E Area closed-bottom lysimeter should be monitored for moisture storage changes at least quarterly for the next 6 years. It should be maintained so that the surface is kept free of all vegetation. The bare surface would simulate tank farm sites, which have been kept vegetation-free, and would optimize the conditions for recharge at this lysimeter. Soil materials from the lysimeter should be sampled and characterized, and water retention and water conductivity parameters should be determined for the soil. After soil characterization is complete, the data sets should be analyzed for consistency and then used to validate UNSAT-H, the unsaturated-flow code that is currently being documented for the Hanford Site. As part of the analysis of the data, the procedures for neutron probe monitoring should be thoroughly reviewed. The review should include the evaluation of the random, instrument, and operator error associated with the data. Procedures should be established and strictly followed for collecting and analyzing the data. These procedures are especially important for all lysimeter studies at Hanford in which neutron probes are used as the primary source of measurements for water balance (evapotranspiration, water storage, and recharge).

Weighing lysimeters are the key to our understanding of evapotranspiration processes in the arid Hanford environment. They have provided all of the available evapotranspiration data that have been used in modeling soil water balance at the Hanford Site (Hinds 1973; Gee and Simmons 1979; Gee and Kirkham 1984). The 300 Area lysimeter sites should be maintained for at least the next 3 to 5 years. The only direct measurements of recharge at the Hanford Site have been made in the 300 Area, and the only complete water balance measurements at Hanford have been made using the 300 Area weighing lysimeters. These two lysimeters are capable of detecting weight equivalent to $\pm 0.02 \mathrm{~mm}$ of water; hence, they are useful in quantifying individual components of the water balance (i.e., evapotranspiration, drainage, and storage changes).

Until additional lysimeters can be built and a 3- to 5-year data set compiled, the 300 Area data set will be the only one useful in testing models that evaluate the effects of climate and plant cover (vegetation) on water balance. This kind of information is needed to develop confidence in the 
long-term model predictions of barrier performance and to estimate recharge rates under the wide range of soil, plant, and climatic conditions that exist spatially and temporally at Hanford.

\section{PROTECTIVE-BARRIER STUDIES}

Water balance measurements for layered profile are needed to support the Protective-Barrier Engineering Studies. These studies are part of the overall Hanford Waste Management Technology Plan (U.S. Department of Energy 1984). Plans are presently being formulated for using lysimetry to evaluate infiltration and drainage on test barrier systems. New lysimeters should be designed to meet the criteria specified in earlier sections and should be compatible with present lysimeter facilities.

\section{ALE SITE WATER DYNAMICS STUDY}

$\mathrm{Pl}$ ans are under way to install weighing lysimeters at the ALE Reserve over the next several years to evaluate water dynamics (particularly evapotranspiration and water storage changes) under conditions of stress and disturbance (drought, fire, etc.). The study is part of a Department of Energy-sponsored arid lands ecology study. However, the lysimeter data gathered at the ALE Reserve (under conditions of higher rainfall, more rapid plant growth, and finer textured soils than are found in the 200 and 300 Areas) should be complementary to the model validation and protective barrier studies that will be conducted in the 200 and 300 Areas over the next several years. The data sets from ALE will provide an additional range of parameters upon which UNSAT-H or any other unsaturated-flow models can be tested. At least two, and possibly as many as four, large weighing lysimeters will be constructed. The proposed lysimeters will be similar in design to the weighing lysimeters in the 300 Area (Kirkham, Gee and Jones 1984). They will be used to evaluate evapotranspiration on at least two sites where the elevation and annual precipitation are higher than those of the 200 Area. 
ADDITIONAL WATER BALANCE STUDIES AT HANFORD

Additional proposed studies to evaluate water balance at Hanford that do not use lysimetry directly include in situ measurements of hydraulic conductivities at selected sites in the 200 Area, micrometeorological measurements of evapotranspiration (Campbell 1977), and tracer migration studies to evaluate the long-term movement of water in the unsaturated zone (Allison, Stone and Hughes 1985). In situ hydraulic conductivity measurements are needed to quantify drainage rates at specific sites at Hanford where lysimetry measurements cannot be made. Measurements of in situ hydraulic conductivity will be made at a number of 200 and 300 Area locations. Soil survey data and geophysical log data will also be used to assess the soil variability and estimate the influence of stratigraphic differences on the drainage characteristics of selected sites.

Evapotranspiration has not been measured directly at any of the waste sites at Hanford. Selected methods such as the Bowen ratio or eddy correlation (micrometeorological) technique will be used to obtain latent heat flux data that can be compared with weighing-lysimeter data for selected periods of time during the year. These data will be used in calibrating the UNSAT-H code and testing the evapotranspiration algorithms used in the code. Tracer studies will complement the lysimeter measurements of water balance. Selective sampling of the 200-W Area S-10 lysimeters for tracer (chloride) migration is proposed as a way to evaluate water migration. Methodology will be developed to analyze the 10-year plume migration from the original tracer zone and to predict travel times from the observed tracer movement in the subsurface, layered soils. In addition, tritium migration studies will be initiated that will look at the migration of tritium at depth in selected, layered soil profiles.

\section{SECTION SUMMARY}

Additional lysimeters are needed to quantitatively assess water balance parameters (drainage and evapotranspiration) at Hanford. The lysimeters need to be designed taking into account the range of soil and plant cover conditions anticipated at Hanford waste sites under present and future conditions. Tests 
of the performance of protective barriers using lysimetry are desirable. Model validation efforts will be enhanced by expanded data bases from lysimeters constructed in the 200-W Area and on the ALE Reservation.

Additional water balance studies being planned for the Hanford Site include in situ hydraulic conductivity tests, micrometeorological studies to estimate evapotranspiration, and tracer tests to predict water travel times in layered soils. These studies will complement the lysimeter tests of water balance in unsaturated zones and enhance our understanding of recharge at the Hanford Site. 


\section{REFERENCES}

Allison, G. B., S. J. Stone and M. W. Hughes. 1985. "Recharge in Karst and Dune Elements of a Semiarid Landscape as Indicated by Natural Isotopes and Chloride." J. Hydrol. 76:1-25.

Baca, R. G., I. P. King and W. R. Norton. 1978. Finite Element Models for Simulating Heat and Moisture Transport in Unsaturated Soils. RHO-SA-31, Rockwell Hanford Operations, Richland, Washington.

Boast, C. W., and T. M. Robertson. 1982. "A 'Micro Lysimeter' Method for Determining Evaporation from Bare Soil: Description and Laboratory Evaluation." Soil Sci. Soc. Am. J. 46:689-695.

Brown, K. W., C. J. Gerard, B. W. Hipp and J. T. Ritchie. 1974. "A Procedure for Placing Large Undisturbed Monoliths in Lysimeters." Soil Sci. Soc. Am. Proc. 38:981-983.

Brownel1, L. E., J. G. Backer, R. E. Isaacson and D. J. Brown. 1975. Soil Moisture Transport in Arid Site Vadose Zones. ARH-ST-123, Atlantic Richfield Hanford Company, Richland, Washington.

Cass, A., G. S. Campbell and T. L. Jones. 1981. Hydraulic and Thermal Properties of Soil Samples from the Buried Waste Test Facility. PNL-4015, Pacific Northwest Laboratory, Richland, Washington.

Cass, A., G. S. Campbell and T. L. Jones. 1984. "Enhancement of Thermal Water Vapor Diffusion in Soi1." Soil Sci. Soc. Am. J. 48:25-32.

Campbel1, G. S. 1977. An Introduction to Environment Biophysics. SpringerVerlag, New York.

Cline, J. F., K. A. Gano, and L. E. Rogers. 1980. "Loose Rock as Biobarriers in Shallow Land Burial." Health Phys. 39:497-504.

Dincer, T., A. Al-Mugrin and V. Zimmerman. 1974. "Study of the Infiltration and Recharge Through the Sand Dunes in Arid Zones with Special Reference to the Stable Isotopes and Thermonuclear Tritium." J.Hydrol. 23:79-109.

Enfield, C. G., J. J. C. Hsieh and A. W. Warrick. 1973. "Evaluation of Water Flux Above a Deep Water Table Using Thermocouple Psychrometers." Soil Sci. Soc. Am. Proc. 37:968-970.

Finlayson, B. A., R. W. Nelson and R. G. Baca. 1978. Preliminary Investigation into the Theory and Techniques of Modeling the Natural Moisture Movement in Unsaturated Sediments. RHO-LD-47, Rockwell Hanford Operations, Richland, Washington. 
Gee, G. W., and C. S. Simmons. 1979. Characterization of the Hanford 300 Area Burial Grounds. Task III-Fluid Transport and Modeling. PNL-2921, Pacific Northwest Laboratory, Richland, Washington.

Gee, G. W., and R. R. Kirkham. 1984. Arid Site Water Balance: Evapotranspiration Modeling and Measurements. Pacific Northwest Laboratory, PNL-5177, p. 38.

Gee, G. W., and P. R. Heller. 1985. Unsaturated Water Fl ow at the Hanford Site. PNL-5428, Pacific Northwest Laboratory, Richland, Washington.

Hammel, J. E., R. I. Papendick and G. S. Campbell. 1981. "Fallow Tillage Effects on Evapotranspiration and Seed-Zone Water Content in a Dry Summer Climate." So il Sci. Soc. Am. J. 45:1016-1022.

Hillel, D. 1982. Introduction to Soil Physics. Academic Press, New York.

Hinds, W. T. 1973. "Small Lysimeters for Measurement of Water Use and Herbage Yield." J. Range Mngt. 26(4):304-306.

Howell, J. V. 1957. Glossary of Geology and Related Sciences. American Geologic Institute. National Academy of Sciences - National Research Council, Washington, D.C., p. 174.

Hsieh, J. J. C., L. E. Brownell and A. E. Reisenauer. 1973. Lysimeter Experiment, Description and Progress Report on Neutron Measurements. BNWL-1711, Pacific Northwest Laboratory, Richland, Washington.

Jackson, R. D., R. J. Reginato, B. A. Kimball and F. S. Nakayama. 1974. "Diurnal Soil-Water Evaporation Comparison of Measured and Calculated SoilWater Fluxes." Soil Sci. Soc. Am. Proc. 38:861-866.

Jones, T. L. 1978. Sediment Moisture Relations: Lysimeter Project 1967-1977 Water Years. RHO-ST-15, Rockwell Hanford Operations, Richland, Washington.

Jones, T. L., G. S. Campbell and G. W. Gee. 1984. Water Balance at an Arid Site: A Model Validation Study of Bare Soil Evaporation. PNL-4896, Pacific Northwest Laboratory, Richland, Washington.

Jones, T. L., and G. W. Gee. 1984. Assessment of Unsaturated Zone Transport for Shallow Land Burial of Radioactive Waste. PNL-4747, Pacific Northwest Laboratory, Richland, Washington.

Jones, T. L., G. W. Gee, J. L. Swanson and R. R. Kirkham. 1983. "A Laboratory and Field Investigation of the Mobility of Cobalt-60 EDTA." In Waste Management 1983, ed. R. G. Post, Vol. 2, pp. 331-333. University of Arizona Press, Tucson, Arizona.

Kimball, B. A., R. D. Jackson, R. J. Reginato, F. S. Nakayama and S. B. Idso. 1976. "Comparison of Field-Measured and Calculated Soil-Heat Fluxes." Soil Sci. Soc. Am. J. 40:18-25. 
Kirkham, R. R., and J.F. Cline. 1982. "Evaluation of Biobarriers for Control of Plant Root Intrusion into Hazardous Waste." In Agronomy Abstracts, 1982 Annual Meetings. American Society of Agronomy, Madison, Wisconsin.

Kirkham, R. R., G. W. Gee and T. L. Jones. 1984. "Weighing Lysimeters for Long-Term Water Balance Investigations at Remote Sites." Soil Sci. Soc. Am. J. $48(5): 1205-1205$.

Last, G. V., P. G. Easley and D. J. Brown. 1976. Soil Moisture Transport During the 1974-1975 and 1975-1976 water Years. ARH-ST-146, AtTantic Richfield Hanford Company, Richland, Washington.

Marshall, T. J., and J. W. Holmes. 1979. Soil Physics. Cambridge University Press, Cambridge, England.

Morrison, R. D. 1983. Ground Water Monitoring Technology. Procedures, Equipment and Applications. TIMCO Mfg. Inc., Prairie Du SaC, Wisconsin.

Morrison, R., and J. Szecsody. 1985. "Sleeve and Casing Lysimeters for Soil Pore Water Sampling." Soil Sci. 139:446-451.

Narasimhan, T. N., A. F. White and T. Tokunaga. 1985. Hydrology and Geochemistry of the Uranium Mill Tailings Pile at Riverton Wyoming. Part II. History Matching. LBL-18526, Lawrence Berkeley Laboratory, Berkeley, California.

Phillips, S. J., A. C. Campbe11, M. D. Campbell, G. W. Gee, H. H. Hoober and K. L. Schwarzmiller. 1979. A Field Test Facility for Monitoring Water/ Radionuclide Transport Through Partially Saturated Geologic Media. Design, Construction, and Preliminary Description. PNL-3226, Pacific Northwest Laboratory, Richland, Washington.

Reisenauer, A. E., D. B. Cearlock, C. A. Bryan and G. S. Campbell. 1975. Partially Saturated Transient Groundwater Flow Model Theory and Numerical Implementation. BNWL-1713, Pacific Northwest Laboratory, Richland, Washington.

Ritchie, J. T., and E. Burnett. 1968. "A Precision Weighing Lysimeter for Row Crop Water Use Studies." Agron. J. 60:545-549.

Ross, B. 1984. "A Conceptual Model of Deep Unsaturated Zones with Negligible Recharge." Water Resources Res. 20:1627-1629.

Sammis, T. W., D. D. Evans and A. W. Warrick. 1982. "Comparison of Methods to Estimate Deep Percolation Rates." Water Res. Bu1. 8(3):465-470.

Stephens, D. B. 1985. "Ground Water Recharge Mechanisms in a Semi-Arid Terrain of New Mexico." In Joint Proceedings of Hydrology Days and the Fourteenth Annual Rocky Mountain Groundwater Conference, April 16-20. Hydrology Days Publication. 1005 Country Club Road, Fort Collins, Colorado. 
Tanner, C. B. 1967. "Measurement of Evaporation." In Irrigation of Agricultural Lands, ed. R. M. Hagan, H. R. Haise and T. W. Edminster, pp. 534-574. Agronomy Monograph II. American Society of Agronomy, Madison, Wisconsin.

Treat, R. L. 1985. "Hanford Grout Technology." In Nuclear Waste Management Semiannual Progress Report, October 1984 Through March 1985, comp. J. L. McEl roy and J. A. Powel1. PNL-4250-7, Pacific Northwest Laboratory, Richland, Washington.

U.S. Department of Energy. 1984. Hanford Waste Management Technology Plan. U.S. Department of Energy, Richland Operations Office, Richland, Washington.

U.S. Environmental Protection Agency. 1982. "Regulations on Unsaturated Zone Monitoring." Federal Register 47(143) Section 284.278, July 26, 1982.

Walter, M. B., M. J. Graham and G. W. Gee. 1984. A Field Lysimeter Facility for Evaluating the Performance of Commercial Solidified Low-Level Waste. PNL-5253, Pacific Northwest Laboratory, Richland, Washington. 


\section{DISTRIBUTION}

No. of

Copies

OFFSITE

L. J. Mezga, Program Manager

Low-Level Waste Management Program

Oak Ridge National Laboratory

P.0. Box X

Oak Ridge, TN 37830

M. J. Barainca, Program Manager

Low-Level Waste Management Program

Idaho Operations office

U.S. Department of Energy

550 Second Street

Idaho Falls, ID 83401

R. Bol and

Waste Management Project

Office

Nevada Operations Office

U.S. Department of Energy

P.0. Box 14100

Las Vegas, NV 89114

T. C. Chee

R\&D and Byproducts Division

DP-123 (GTN)

U.S. Department of Energy

Washington, DC 20545

B. W. Church, Di rector

Health Physics Division

Nevada Operations Office

U.S. Department of Energy

P.0. Box 14100

Las Vegas, NV 89114

Marty Mifflin

Desert Research Institute

2505 Chander Ave. \#1

Las Vegas, NV 89120
No. of

Copies

F. Gorup, Program Manager

Nuclear Waste Management Group

Chicago Operations Office

U.S. Department of Energy

9800 South Cass Avenue

Argonne, IL 60439

J. J. Jicha, Di rector

R\&D and Byproducts Division

DP-123 (GTN)

U.S. Department of Energy

Washington, DC 20545

E. A. Jordan

Low-Level Waste Proyram

Manager

Division of Storage and

Treatment Projects

NE-25 (GTN)

U.S. Department of Energy

Washington, DC 20545

R. L. Walters

Ecological Research Division ER-75

Office of Health and Environmental Research, OER

U.S. Department of Energy

Washington, DC 20545

D. B. Leclaire, Di rector

Office of Defense Waste and Byproducts Management

DP-12 (GTN)

U.S. Department of Energy

Washington, DC 20545

30 DOE Technical Information Center

Technical Library

Argonne National Laboratory

Argonne, IL 60439 
No. of

Copies

Peter Colombo, Group Leader Nuclear Waste Research

Brookhaven National Laboratory Building 701

Upton, NY 11973

E. A. Jennrich

Low-Level Manayement

Program

EG\&G Idaho, Inc.

P.0. Box 1625

Idaho Falls, Idaho 83415

Environmental Protection Agency

Technology Assessment Division

Office of Radiation Programs

Washington, D.C. 20460

Technical Library

Idaho National Engineering Laboratory

Idaho Falls, Idaho 83401

J. G. Steger

Los Al amos National Laboratory

P. 0. Box 1663

Los Alamos, NM 87545

Technical Library

Los Al amos National Laboratory

Los Alamos, New Mexico 87545

National Academy of Sciences

National Research Council

2101 Constitution Avenue

Washington, DC 20418

J. S. Baldwin

Low-Level Waste Management Program

Oak Ridge National Laboratory

P.0. Box X

Oak Ridge, TN 37830

T. E. Hakonson

Los Al amos National Laboratory

Los Alamos, NM 87545
No. of

Copies

\section{J. W. Nyhan}

Los Al amos National Laboratory

P. 0. Box 1663

Los Al amos, NM 87545

Technical Library

Oak Ridge National Laboratory

Oak Ridge, Tennessee 37830

E. W. Kendall

Waste Management Project Manager REECO

P.0. Box 642

Mercury, NV 89023

J. J. Blakeslee, Program Manager

Nuclear Waste Processing

Rockwell International

P.0. Box 464

Golden, C0 80401

C. E. Wickland

Manager, Waste Operations

Rockwe 11 International

Rocky Flats Plant

P.0. Box 464

Golden, CO 80401

J. C. Corey

Savannah River Laboratory

P.0. Box A

Aiken, SC 29801

I. W. Marine

Savannah River National Laboratory

Box A

Aiken, SC 29801

Technical Library

Savannah River National Laboratory

Aiken, SC 29081

E. M. Romney

University of California at Los Angeles

Westwood, CA 96137 
No. of

Copies

0. D. Markham

U.S. Department of Energy

Idaho Operations Office

Radiological and Environmental Sciences Laboratory

Idaho Falls, ID 83401

P. J. Wierenga

Dept. of Soil Science

New Mexico State University

Las Cruces, NM 88004

W. A. Jury

Department of Soils

University of California

Riverside

Riverside, CA 92502

J. W. Cary

U.S. Department of Agriculture

Snake River Conservation Research Center

Route 1, Box 186

Kimberly, ID 83341

Jack Fischer

Low-Level Radioactive Waste Program

U.S. Geological Survey

Water Resources Division

12201 Sunrise Valley Drive

Reston, VA 22092

I. J. Winograd

Geological Survey

National Center - Mail Stop 432

Reston, VA 22092

E. P. Weeks

U.S. Geological Survey

Federal Center Mail Stop 413

Denver, CO 80225

Jeanne Rensel

$\mathrm{Hi-Level} \mathrm{Waste} \mathrm{Management}$

Washington State Department of Ecology

Pu I I

Olympia, WA 98504
No. of

Copies

Dan Stephens

Dept. of Geosciences

New Mexico Tech

50 Corro, NM 87801

E. O'Donnell

Earth Sciences Branch

Division of Health, Siting and Waste Management Research

U.S. Nuclear Regulatory Commission

Washington, DC 20555

F. Swanberg

Division of Health, Siting and Waste Management Research

U.S. Nuclear Regulatory Commission

Washington, DC 20555

G. S. Campbe 11

Washington State University

Pullman, WA 99164

T. J. Nicholson

Nuclear Regulatory Commission

Div. Health, Siting and Waste Management

MS 1130 SS

Washington, DC 20555

Jonathan Herrmann

Office of Solid Waste

U.S. Environmental Protection Agency

Municipal Environmental Research Laboratory

Cincinnati, $\mathrm{OH} 45268$

ONSITE

Hanford Engineering Development Laboratory

R. E. Lerch 
No. of

Copies

6 Richland Operations Office

E. A. Bracken

R. A. Holten

N. T. Karajianes

H. E. Ransom

J. D. White

J. K. W. Wukel ic

22 Rockwell Hanford Operations

M. R. Adams

J. F. Albaugh

S. Baker

G. A. Beitel

L. C. Brown

W. H. Chapman-Riggsbee

C. DeFigh-Price

W. F. Heine

R. E. Isaacson

W. A. Jordan

G. G. Meade

S. J. Phillips

R. D. Prosser

J. F. Relyea

J. H. Roecker

R. C. Routson

D. L. Sanders

W. W. Schulz

J. C. Sonnichsen

S. A. Wiegman

G. F. Williamson

D. E. Wood
No. of

Copies

United Nuclear Industries

D. R. Pratt

46 Pacific Northwest Laboratory

P. A. Beedlow

J. B. Burnham

D. W. Dragnich

J. L. Downs-Berg

F. H. Dove

M. J. Fayer

G. W. Gee (10)

C. A. Geffen

M. J. Graham

H. A. Haerer

M. S. Hanson

J. N. Hartley

P. C. Hays

P. R. Heller

T. L. Jones (5)

C. T. Kincaid

R. R. Kirkham

I. C. Nelson

A. E. Reisenauer

L. E. Rogers

R. L. Skaggs

R. J. Serne

C. S. Simmons

S. L. Stein

J. A. Stottlemyre

G. P. Streile

Technical Information (5)

Publishing Coordination (2) 